\title{
5 \\ A new production culture and non-commodities
}

After the two turns in Soviet material and visual culture - the Khrushchevera aesthetic turn and the mid-1960s anti-functionalist turn - Soviet material culture became a site of great plurality and diversity, otherwise rarely associated with the Brezhnev era. Whereas VNIITE theorists explored the possibilities of flexible and user-sensitive systemic designing, as the preceding chapter has discussed, the critics and practitioners of decorative art chose self-reflection as their foremost professional strategy.

This choice had two important consequences. First, decorative artists gravitated further towards more complex forms. While between the late 1950s and early 1960s applied artists expected the Artists' Union to facilitate the production of 'simple and neat objects', ${ }^{1}$ and critics saw 'beauty in simplicity', ${ }^{2}$ a new view was expressed beginning around 1963 that now 'everything is much more complicated'. ${ }^{3}$ By the 1970 s, the complexity of material objects became not only undeniable but also welcome. Evaluating the 1970 All-Union Decorative Art Exhibition in Moscow, dedicated to Lenin's 100th birthday, the editorial team of Dekorativnoe Iskusstvo SSSR noted the exhibition artists' skill in solving 'complex, and sometimes deliberately complicated tasks'. ${ }^{4}$ If at this point 1960s neodecorativism was often still seen by critics as a creative laboratory for mass-produced objects, 1970s decorative art affirmed the social value of complex designs, hardly adoptable for mass production. Simplicity lost its status as a universal value in socialist material culture and ceased to be a necessary characteristic of a comradely object.

The increasing distance from mass production was motivated by the professional ambition to elevate decorative art to the level of philosophical exploration, to make it a forum for discussing the universal human condition like any other field of art. As in the early 1950s, artists working with ceramic, glass, textiles and other materials demanded that they be 
recognised as proper artists. This time, however, their argument did not hinge on the indispensability of the objects they designed to people's daily lives, but on the rich potential of the material to express complex ideas the artists proposed a non-utilitarian materiality. A ceramic artist could now be like a sculptor or, even better, a painter; ceramics were more powerful and eloquent than the traditional materials of fine art. This new argument echoed contemporary discussions of decorative arts and crafts in the United Kingdom. According to Judy Attfield, professional craftspeople often rebranded their work as 'applied art' or 'decorative art' in the 1970s, hoping to gain public acceptance for their work as art. 'To those critics who saw craft as a retreat from innovation, modernism and progressive design, the bid was to elevate its status by redefining craftwork as a "creative" art and "craftspeople" as designer-makers with the right of entry into the circle of respectability enjoyed by fine artists. ${ }^{5}$ Although this ambition remained unrealised, British decorative arts did achieve some prestige as a middle-class profession through the growth of degree courses on ceramics, woodwork, plastics, jewellery and metalwork. In the Soviet Union, however, the decorative artist did not want a middle-class status - officially still non-existent in Soviet society - but rather yearned to enter the intelligentsia and take part in its traditional role as an educated sub-community cultivating critical attitudes in society. While not openly criticising the Soviet system and not taking the dissident path, decorative artists in the Brezhnev era navigated the muddy waters of late socialist cultural policy in order to make a difference in Soviet aesthetics and consumer culture through their mastery of materials. They attempted to make their objects say more than the official vision of decorative art allowed. They aspired to create much more than just commodities.

This chapter examines the development of non-utilitarian objects in the changing political, economic and social climate of the Brezhnev era. It begins by examining the mass redefining of Soviet material and visual culture at a time when many once considered rigid lines blurred: between arts, between types of objects and between modes of creative work. Further, this chapter addresses a recurrent and painful problem, first clearly formulated by the Russian avant-garde: the role of the artist in industry and mass production. The first section will focus on an interview series conducted by the Dekorativnoe Iskusstvo SSSR team in 1973 with artists, engineers and administrators at several Soviet factories that produced household objects. Then, proceeding to the mid-1970s, this chapter will discuss design professionals' investigation of the messages that 'talkative' objects conveyed to exhibition viewers and to everyday users. Finally, the chapter will outline the case of a Leningrad group of ceramic artists, One Composition, active from 1977 to 1986, as they exemplify the major inquiries and preoccupations in decorative art of the Brezhnev era - most of all, its anti-commodity stance. 


\section{Celebrating clashes}

From the mid-1960s, the All-Union exhibitions of decorative art became forums for lively professional debates about the social/economic responsibility of artists as much as about the aesthetic criteria of art. The 1968 exhibition prompted a clash of opinions between artists and critics: while some, such as Iurii Gerchuk, sensed the imminent crisis of decorative art, others - for example, Nonna Stepanian, Liudmila Kramarenko, Kirill Makarov and Boris Smirnov - attempted to reclaim the value of decoration in post-industrial society. The professional community of decorative art specialists welcomed this clash as clearly being a positive, productive development, and Dekorativnoe Iskusstvo SSSR repeatedly propagated this idea. At the roundtable of the 1968 exhibition, Belarusian designer and critic Oleg Surskii refuted some of his colleagues' worries that the reconsideration of aesthetic ideals brings chaos and harm to art:

Probably, what is happening is a very deep insight into a certain new, sharper, probably more extravagant aesthetic pattern. We are learning subtleties that we have missed in a crystal-clear system [of modernist aesthetics]. In the current disarray and vacillation, we can notice new connections, a new structure, and new artistic possibilities. ${ }^{6}$

By the next All-Union decorative art exhibition, held in the spring of 1970 in the premises of the USSR Academy of Arts and dedicated to Lenin's 100th birthday, perpetual confusion and indecision were broadly recognised as legitimate facts of Soviet artistic life, mostly due to the policy of Dekorativnoe Iskusstvo SSSR. Reporting on the 1970 exhibition, one editorial in Dekorativnoe Iskusstvo SSSR deliberately addressed professionals of different persuasions, believing that a 'clash of opinions will help with clarifying the crux of the matter' ${ }^{7}$ Notably, these professionals included both critics and artists, whose view on the future of decorative art varied according to their different positions in relation to it. With regard to decorative artists who were active from the late 1960s to the 1980s, their attitude to critical concepts and debates ranged from the indulgent ('let them talk their talk, while we do the actual work') to the sceptical and even dismissive. ${ }^{8}$ However, during the 1970s, Dekorativnoe Iskusstvo SSSR often gathered artists and critics together by publishing their opinions in one section of the journal, or in person at roundtables. In the long discussion of the 1970 exhibition that occupied the majority of Dekorativnoe Iskusstvo SSSR's September issue, the artists' words appeared on the very first pages, before giving way to the critics. This contraposition signalled the radicalisation of the post-Stalin aesthetic regime of arts, based not only on equalising different arts, but on the constant tension and clash between different opinions in search of new material forms and new symbolic meanings. 
Several participants in the 1970 exhibition expressed their views on the urgent practical and conceptual problems of Soviet decorative art and the mass production of household goods in response to Dekorativnoe Iskusstvo SSSR's interviews. Iurii Zhul'ev, the head artist of the Vosstanie glass factory in Chudovo, Novgorod oblast', contributed to the exhibition with his utilitarian services - clean forms, easily reproducible, intended for everyday use. Though a 'man of industry', he nonetheless admitted to being susceptible to fashion, 'like all artists', and driven towards creating 'useless' objects, such as 'a still life in glass'. Justifying this desire, he referred to the 'theorists' who 'argue that decorativeness is also a function': thus, instead of dismissing the critics' vocabulary, the artist adopted it strategically to make sense of his move beyond simply serving the production line. ${ }^{9}$ This alternate function was, according to Zhul'ev's reasoning, a creative response to the problem of backward technology: 'We cannot have any design until we get [proper] machines.' While the mass production of household objects was hampered by technological flaws in Soviet factories, artists could affect society by presenting the unexpected, the unusual, by producing a 'strong impression'. This impression, in turn, could be produced by metamorphoses of materiality, such as using one material to imitate another (e.g. making glass look like metal through gilding) or contrasting different materials in one artwork. Zhul'ev especially noted jewellery by an Estonian Juta Paas-Aleksandrova, the head artist of the Russkie Samotsvety factory in Leningrad. Her combination of metal and fur made Zhul'ev think not only about the Monomakh's cap, a famous Russian medieval crown stored at the Kremlin Armoury, but also of Meret Oppenheim's 'Object' ('Breakfast in Fur' 1936) - a fur-covered teacup, saucer and spoon that caught Zhul'ev's attention 'in the catalogue of some foreign exhibition'. Although, to Zhul'ev, Oppenheim's work looked 'somewhat vulgar', he believed such a provocative use of materials was a necessary stage to pass for Soviet decorative art. ${ }^{10}$

Other artists' voices, presented by Dekorativnoe Iskusstvo SSSR, echo this anticipation of bolder techniques. The glass artist team of Galina Antonova, Svetlana Riazanova and Antonina Stepanova admitted that designing household objects for factory production did not allow them 'to say much'. The work on unique compositions for public interiors, on the other hand, gave more room for expression. The trio preferred creating objects that were not 'habitually classifiable', but, instead, 'decorative, festive and surprising'. ${ }^{11}$ The notion of festivity came to the fore in an interview with the exhibition's 'star', Boris Smirnov. He noted that the shift from asceticism to decorativeness in Soviet material culture was, on the one hand, part of the international trend towards complexity in design aesthetics, and, on the other, a response to the official mandate to design festivals to celebrate the 50th anniversary of the Bolshevik Revolution in 1967 and Lenin's jubilee. 'For three years we, Soviet people, have been 
saturated with celebratory mood. We [decorative artists] have been concerned less with household objects for everyday life and more with objects for exhibitions.' However, this was not a misfortune, Smirnov continued, in response to some worried art critics such as Iurii Gerchuk and Tatiana Semenova. Rather, this was an achievement. The frustration of an exhibition viewer, unable to find the exhibited objects in mass production, was not the artists' fault, but the result of 'subsidiary circumstances', Smirnov claimed. By 'subsidiary circumstances', he evidently meant the rigidity of the planned economy and the lack of proper technology to adequately adapt artists' innovative designs into mass production.

As was discussed in Chapter 3, Smirnov used the forms of everyday objects not for practical usefulness but for defamiliarisation (a concept he borrowed from the literary theorist Victor Shklovsky, though not explicitly). Designing teapots with soldered lids or vessels conjoined with human and animal figures, as in his latest composition 'Man, Horse, Dog and Bird', Smirnov intended to defamiliarise the forms of commodities, to cause the viewer to reconsider household objects - vases, teapots, etc. - as things full of symbolic meaning. In constructing these meanings, Smirnov emphasised, matter was important: the transparency of glass allowed him to 'defamiliarise ordinary daily collisions, to inspire thinking'. ${ }^{12}$ Like Zhul'ev, Smirnov referred to the example of pre-war Western modernist art, although as antithesis rather than as inspiration. A Western readymade artist, such as, for example, Man Ray with his 1921 Gift (an iron with thirteen thumb tacks), was, according to Smirnov, just 'kidding around', not expecting a serious response from the viewer. Meanwhile, Smirnov's teapots referenced the images of nineteenth-century Russian tea-drinking in merchant homes and taverns, described by the playwright Nikolai Ostrovsky and painter Boris Kustodiev, thus appearing as allusions to the material culture of the past, not simply trivial objects. ${ }^{13}$ Smirnov refused to recognise that the Dadaists and Surrealists also rescued household objects from the banality of everyday life, as Bill Brown argues in his 'Thing Theory'. ${ }^{14}$

Whereas the artistic voices in the 1970 exhibition seemed to celebrate 'useless' forms and surprise in unison, the opinions of the critics varied. Iurii Osmolovskii, an art historian specialising in painting, admitted that, in spite of his insufficient expertise in decorative art, he could see the loss of its 'democratic-and-vital basis' that had been no less than the 'artistic intervention into human habitat'. Exhibited in glass cases, the contemporary objects were alienated, non-belonging and devoid of a consumer, Osmolovskii complained..$^{15}$ This alienation, however, was explained not as an agency of objects beyond consumer culture - a thing-power, as Jane Bennett would describe it - but by the overgrown artistic ego. The artists now addressed their objects not to consumers but to exhibitions, that is, to themselves for the purposes of self-promotion: 'Today, looking at a cup, 
we think not "what a cup!” but “what an artist!".'16 Additionally, even if this cup - or vase, or teapot - is used to express a philosophy of the new everydayness (filosofiu novogo byta), they fail to do so because they are devoid of a functional form. According to Osmolovskii's logic, a perfectly useful teapot can adequately express modern everydayness, but a teapot with a soldered lid cannot - when an object 'is trying to stop being an object', it gets stuck between functionality and 'pure thought', making no sense. ${ }^{17}$

Iurii Gerchuk spoke with similar scepticism, reiterating his criticism from the previous year. Like Osmolovskii, he warned about the alienation of objects from consumption and compared the latest exhibitions of decorative art to quasi-theatrical plays. Thinking of an object as a theatre prop, an artist imagines a consumer as a mask, or even a range of different masks, and so consumption turns into a masquerade. This work cannot be serious and consistent: 'Maybe tomorrow we'll wish to try yet another costume.' The rhythmic structure of these theatrical objects reminded Gerchuk of the fin-de-siècle art group Mir Iskusstva (World of Art) that was inspired by Art Nouveau decorativism, symbolism and retrospectivism, and also particularly by the eighteenth-century Russian variants of Baroque and Rococo. In Gerchuk's opinion, contemporary decorative artists' retrospective fascination with the aesthetics of Mir Iskusstva (I would call this second-level retrospectivism) was merely 'skimming the cream' from this heritage without understanding it thoroughly. ${ }^{18}$

Evgenii Rozenblium, co-founder and head of the Senezh studio, took a different stance. He saw a clear purpose in seemingly useless objects: creative consumption, that is, the transfer of creative impulse from an artist to a consumer. Even if an object lacks practical applicability, it can satisfy 'everyone's need for independent creative choices'. That is, by purchasing or even merely observing an object, one is making a creative choice. Objects for creative consumption, Rozenblium believed, could be equally useful at an exhibition, at home or at work: this position echoed the avant-gardist object that would act as co-worker and life organiser. Consequently, Rozenblium argued against the division of objects into 'decorative' and 'utilitarian' and even against the distinction between 'decorative artists' and 'designers'. Instead of the professional divide, Rozenblium placed the freedom of choice between a whole range of things and their uses. He identified three kinds of freedom in designing objects: formal, relating to the creative process; functional, relating to the different ways to use an object; and psychological, allowing both the artist and the consumer to feel their creative potential. Designing objects is a social need, Rozenblium argued, regardless of material well-being. Moreover, he concluded, there was no need to worry about the proliferation of disparate stylistic references: it was not eclecticism, but a normal process of searching for the new principles of form-giving, which would eventually lead to a 'new integrity'. 19 
The following commentary decisively refuted Rozenblium's optimism. Aleksandr Kamenskii, the advocate of the monumental, simple forms of Khrushchev-era painting, for which he coined the term 'severe style', dismissed the new decorative art as philistine and a throwback to the Stalinist 'architecture of excess'. There was nothing to take home from the 1970s exhibitions, he argued - both figuratively and literally - because a Soviet person just cannot dream of pretentious teapots and the like. Despite his overt criticism, however, Kamenskii unwittingly acknowledged the thingpower of the exhibits: they are 'immodest', they 'stamp their feet' capriciously, they 'flirt', as if a visitor must 'walk on egg-shells around them'. These 'thing-characters' and 'thing-fetishes' did not seem, to Kamenskii, to be capable of facilitating the 'sustainable byt of a contemporary person'. Thus, contrary to Smirnov's proclamation of striving beyond commodity culture, Kamenskii viewed experimental decorative art as the manifestation of commodity fetishism, as a poor alternative to the uniform, prefabricated material environment.

This strong statement, in turn, was discredited by Kirill Makarov, the foremost advocate of late 1960s neodecorativism. There are no genuine reasons for rebuking artists for 'easelism' and 'folderols' (ukrashatel'stvo), he argued. In defending this argument, however, Makarov acted as the antithesis to Rozenblium, with whom he otherwise shared sympathy regarding the new tendency. While Rozenblium stood for the merger of professional activities, for Makarov the distinction between them was important, because it justified the new experimentation with figurativeness and ornamentation. He tried to reassure his colleagues, who were worried about the dawn of the rigorous modernist aesthetics, that what they were witnessing was by no means the return of Stalinist grandeur:

The problem of the late 1940s-early 1950s was not the creation of unique objects, but the extension of the principles of uniqueness, figurativeness and, eventually, easel-ness [stankovosti] on to the whole sphere of decorative art, including mass production, which led to superficial application of decoration [prikladnichestvo] of all sorts.

The situation in 1970 was very different, Makarov continued, because now not only art criticism, but 'real life' demanded that there be differences between unique works of decorative art and mass-producible objects. His further suggestion to use the term 'decorative art' recalled the 1962 attempt to use it as an umbrella term for different types of art and $\mathrm{craft}^{20}$ but was now informed by the institutional and conceptual changes of the early Brezhnev years:

Today, decorative art appears in different forms: in the form of creating unique and limited-edition objects of predominantly decorative character; in the form of the products of artistic industry; in the form of mass production [based on the prototypes] of artistic engineering; finally, in the form of folk and amateur 
art. This differentiation in the sphere of material-artistic production requires a differentiating approach to analysing phenomena. ${ }^{21}$

Makarov's four-part scheme - unique/limited-edition exhibits; traditional production of household items from ceramics, glass, textiles, etc. ('artistic industry'); industrial design; and, finally, folk/amateur art - was, evidently, not another attempt at ordering terms, but a championing of diversity in object-making. This was differentiation for the sake of diversification, not for the sake of control and constraint. Seen in this light, his argument was not so different from Rozenblium's: in the former, decorative art was to merge with industrial design, while in the latter it was to encompass it. Decorative art, as a summation of diverse creative activities and produced objects and as a heterogeneous 'material-artistic production', was capable of having a strong impact on society. Makarov believed that as well as satisfying everyday needs, decorative art could and should also form them; this is why he considered an exhibition as important as a shop window. The ultimate mission of decorative art is the "transformation of our byt' by going above the daily routine, by diverting our attention from stressful tasks and chores to the 'integral and joyful perception of the world', by awakening 'the memory of the dear and intimate past' and by 'directing us to the future'. The past that Makarov referred to was definitely not the moral and aesthetic crimes of the Stalin era, but rather a personal, intimate past, expressible in objects and in tactile and visual pleasures. The appeal to this cherished past, safeguarded from collective trauma, is what, at the beginning of the 1970s, distinguished decorative art from the decorativism of the Stalin era. Makarov's commentary, therefore, can be seen as a rehabilitation of all sorts of decoration, even those deemed excessive by the devotees of the Khrushchev-era aesthetic turn.

The idea that prototypes for industrial mass production, unique or limited-edition exhibition-oriented objects and small series of traditional 'artistic industries' all constitute one category of 'decorative art' became the mainstream attitude in Dekorativnoe Iskusstvo SSSR in the early 1970s. Critics identified common principles in all these various creative professions, tracing how these same principles were shaped into the objects they produced. Sculptor Dmitrii Bisti, for example, viewed the all-Union Youth Exhibition of 1972 as the manifestation of a fundamental unity of Soviet visual culture. This was the first Soviet art exhibition to display the work of artists younger than 35 , who belonged to the youth section of the USSR Artists' Union and had been organised by the Union's youth committee established a year earlier. ${ }^{22}$ Held in the prestigious Manege exhibition hall in Moscow, the exhibition was remarkable due to the unprecedented combination of design projects and decorative (in the older, narrower sense) and easel art displayed together. This was possible because the exhibited design projects belonged to the Senezh studio, which was supervised by 
the USSR Artists' Union, and was labelled 'artistic projecteering', meaning that it was classified as conceptual design and not commissioned designs to be mass produced. Senezh studio was unique in this regard. A design project by VNIITE, an artistic-construction bureau or a factory design service would not have been admitted into an art exhibition. However, for Bisti, a sculptor, Senezh projects represented Soviet design in general and signalled a seamless visual culture; he noticed no ruptures between the exhibition sections. His conclusion was that design and easel art were based on common principles, and as such 'designers are not some special breed remote from artists', but rather could be the very same people whose easel graphics or theatre props were on display in the same exhibition. Bisti argued that in addition to the conceptual interiors and urban environments, as in the case of Senezh studio, it was not possible to design everyday objects and machines without fundamental knowledge of the basics of visual art. His encompassing understanding of design was similar to Makarov's inclusive understanding of decorative art: it was all activities directed at shaping the material environment, including the home, the street, the workplace and all public places. Such design, according to Bisti, was based on image-conceptualisation (obraz). Designers and easel artists all work with composition, volume, space, and can learn from their respective approaches to these categories. Both design and easel art improve from mutual interaction and entanglement, and one can benefit from working in both professions. ${ }^{23}$

At the same time as the youth exhibition, another important exhibition, 'Artistic Glass of the Factories of the Russian Federation', was held at the Academy of Arts. This event also inspired critics to reflect on the openness and interconnectedness of Soviet visual and material culture. According to the Leningrader Nina Vasilevskaia, the anti-functionalism of contemporary artistic glass was a positive tendency, appropriate for the historical moment: 'The epoch when personal and social, the earthly and the cosmic, the contemporary and the historical are tightly intertwined in everyone's consciousness demands a new image-bearing structure of plastic arts.' ${ }^{24}$ The term 'plastic arts' included easel, monumental and decorative art in all their diversity, as a single visual and material system carrying a range of meanings, from intimate to global. The border between 'easelism' and 'monumentalism' was disappearing, whereas decorative art could accommodate both characteristics. As a result, Vasilevskaia noted, decorative art transmitted artists' beliefs, and it was this 'sharp intellectualism', rather than any formal qualities of artworks, that made decorative art truly modern. Predicting the irritation of some fellow critics, she stressed that the new permeability of art was notably different than it had been for 1950s kitsch, which was exemplified by poor copies of Repin's and Surikov's masterpieces on lacquer boxes and vases. ${ }^{25}$ This new 'easelism' was very serious and self-reflective. 
The artist as producer, the artist vs. production

Although this clash of opinions in Dekorativnoe Iskusstvo SSSR may seem abstract, it essentially revolved around the problem of bringing decorative art closer to the reality of Soviet daily life and consumer culture without damaging its artistic quality. The concerns of people such as Osmolovskii, Gerchuk and Kamenskii did not just stem from their stubborn vision of decorative art as 'applied' and 'utilitarian', but from the discrepancy between the Brezhnev government's celebration of socialist consumption and the systemic failures of Soviet light industry to provide desired goods to everyone. Prime Minister Aleksei Kosygin's reforms were intended to boost production by introducing some flexibility and incentives for the workers, but they proved untenable and were abandoned by 1970 . While commitment to citizens' prosperity was Brezhnev's strategy to oppose the voluntarism of his predecessor and maintain his own popularity, the quality of consumer goods could not steadily grow because of systemic industrial flaws, such as outdated equipment, poor supply of materials, and the ongoing prevalence of quantitative plan indicators that precluded qualitative improvement. At the same time, as Natalia Chernyshova demonstrates in her study of Brezhnev-era consumption, by the 1970s Soviet people had grown more familiar with Western consumer goods through exhibitions, films, literature and because of the increasing number of imported goods from Western and Eastern Europe, however limited. This made them more discriminating and demanding consumers who were not willing to simply grab whatever the shops were selling. They wanted more and expected the government to be true to its promises. ${ }^{26}$

Given this change in Soviet consumerism in the 1970s, bold experiments by decorative artists might have indeed appeared as nothing more than self-gratification, annoying consumers. It was clear that simple appeals to the social duty of artists would not change the situation without a significant improvement in the condition of artists' work in industry. Therefore, the Dekorativnoe Iskusstvo SSSR editorial team understood that it was not enough to publish disputes among artists or to reiterate the 1920s slogan 'into production' repeatedly. In the early 1970s, it seemed necessary instead to highlight the major tensions between artists and other factory employees and detail the urgent problems of production, in order to find possible solutions to the ongoing professional conflicts at factories and render artists' bursting creativity actually useful in mass production.

In 1970 the journal covered a conference held as a joint event with the Jubilee exhibition that was dedicated to the problem of artistic labour in industry. Organised by the Soviet Academy of Arts, the Artists' Union and the Ministry of Culture of the USSR, the conference brought together artists working in factories, art critics and government officials from var- 
ious levels. ${ }^{27}$ In his welcoming speech, the president of the Academy of Arts, sculptor Nikolai Tomskii, brought up the troubling dilemma of Soviet decorative art: the general increase in artistic creativity and the quality of designs had little actual effect on mass-produced products. He more or less reiterated the official view that decorative art was creative work in the service of the economy, according to which no daring design could go 'merely' to an exhibition or be placed in a public interior. All successful works of decorative art must 'necessarily go into production and be available either in limited edition or in large circulation' and thereby offer 'everyday joyful companionship' to people. However, this would not be possible until both the financial and technological profiles of industry were determined by stylistic tendencies and quality standards. Such a hierarchy of settings, in turn, was possible only by giving artists more power in decision-making. The chief artist (glavnyi khudozhnik) should have the status of art director at a factory, equal in status with a technical director. The position of the artist in industry must finally be solidified by a consistent decree, and all factories producing household objects must institute an official position of 'artist-productivist' - here, Tomskii used the exact term as it had been used in the 1920s. Leonid Karateev, the secretary of the Artists' Union, added that unique experimental works and prototypes for mass production were "the two inseparable sides of one whole process of the development of Soviet decorative art'. The glass artist Svetlana Beskinskaia made some practical requests: more room for creative work in factory workshops, the artists' right to have free copies of their own work, and regular industrial design exhibitions in addition to decorative art exhibitions. The main suggestions of the conference were forwarded to the relevant ministries. ${ }^{28}$

The discussion progressed to the next stage in 1973, when the Academy of Arts hosted an exhibition for Russian artistic glass factories and the Leningrad Factory of Artistic Glass celebrated its 25th anniversary. The problem of art in production now involved material, financial and administrative aspects. Since the mid-1960s, glass art had been the leading arena of innovation in Soviet decorative art and the most noticeable material used in neodecorativism. Boris Smirnov, thanks to his daring 1960s experiments with surprising and defamiliarising objects, appeared in Dekorativnoe Iskusstvo SSSR as the driving force behind glass as an avant-garde material. While other glass artists, too, did receive attention in the journal in the 1960s, the 1973 issues presented for the first time a comprehensive panorama of artists' profiles which included current social and economic challenges. Congratulating the Leningrad Factory of Artistic Glass - the leading producer of unique and limited-edition lead glass items - on its 25th anniversary, the Dekorativnoe Iskusstvo SSSR editorial team emphasised the importance of good management for maintaining efficient cooperation between different specialists. Honouring such veterans 
of the 1920s and 1930s Russian avant-garde as the previously mentioned Smirnov and Eduard Krimmer, a student of Kazimir Malevich, who had worked for the factory since its opening in 1948, the editorial presented their work as artists as being inextricable from the administrative skills of the factory's director Ivan Dmitriev and art director Ekaterina Ianovskaia. ${ }^{29}$ It was thanks to Dmitriev's expertise as a professional chemist, the editorial stated, that the factory was approved by the Ministry of Trade in the late 1940s to start working on lead glass production that was costly and labour-intensive, but also visually impressive. In 1965 Dmitriev obtained permission for the factory to end the production of regular glassware altogether and become a specialised producer of high-quality lead glassware. ${ }^{30}$ This new specialisation entailed the 'steady expansion and updating of the variety of goods' and strengthened the Leningrad factory's tradition of close cooperation between artists, manufacturing technicians and craftspeople - glassblowers, grinders and engravers. ${ }^{31}$

The Leningrad Factory of Artistic Glass became the first in the Soviet glass industry to test the Kosygin reforms by introducing welfare and bonuses for innovations in design and technology. As a result, the factory's production was completely updated by the early 1970s, and even though the government discontinued the reforms on the all-Union level, Dmitriev continued to stimulate technological and artistic modernisation in the factory. As the art critic Nikita Voronov stated enthusiastically, 'the artists could [better] see their goal when their ideas became embodied in real objects' - not only due to the greater freedom in planned targets, but also due to Dmitriev's introduction of 'creative days', when artists could focus on their experiments, and by increasing the number of research trips. ${ }^{32}$ For her part, Ianovskaia demonstrated a striking combination of artistic and managerial skills, giving 'keen attention to each artist' and channelling their different personalities towards common practical goals. ${ }^{33}$ The cumulative effect of economic incentives, the support for artistic experimentation, and the cooperation between different specialists made the Leningrad Factory of Artistic Glass a role model for the Soviet artistic industry: the factory provided limited-edition and medium-scope collections for retail trade while also receiving numerous awards at domestic and international exhibitions. ${ }^{34}$

The tone of Dekorativnoe Iskusstvo SSSR in the editorial suggested that even though Ianovskaia and Dmitriev were outstanding managers, they were not unique: every administrator, with due effort, could raise their factory's production to the same level of success. In the meantime, the factory administration could boast to foreign delegations: 'Objects that are true works of art had been recently considered exhibition pieces, but now they are available for wide consumption.' Leningrad lead glass - or 'Leningrad crystal' - became an internationally known brand not only through exhibitions but also through high-quality household goods avail- 
able almost everywhere - at least in all major cities - from Ukraine to the Russian Far East. Moreover, the factory leadership was sure to note that "people in Italy, the Netherlands, Sweden and Finland can buy goods with the label of the Leningrad Factory of Artistic Glass' ${ }^{35}$ By the time the government increased the import of goods in an effort to mitigate the growing consumer crisis, ${ }^{36}$ the practice of exporting goods - even though on a very limited scale - was already outstanding and benefited the factory's reputation within the Soviet Union. While this success story may sound like a typical case of Soviet exaggeration, the archival records of a consultation of factory employees and trade workers in 1973 demonstrates that the latter were satisfied with the timely supply and high quality of the products, although they still identified areas for further improvement. ${ }^{37}$

This success story by no means obscured the ongoing tensions between artists and other workers in factories. On the contrary, it provided a convenient opportunity to highlight them. Praising the scope, diversity and clear composition of the exhibition 'Artistic Glass of the Factories of the Russian Federation' that had grown out of the 1970 conference on artists in industry, Dekorativnoe Iskusstvo SSSR urged its readers to 'think about unresolved problems'. 'When, at last, will glass factories produce medium and large editions of the objects which, just like exhibition items, demonstrate the hard work and fantasy of artists?' inquired the editorial, directly addressing the Soviet Ministry of the Industry of Construction Materials. ${ }^{38}$

To lend credence to this issue, the journal published artists' answers to a questionnaire it sent out - artists currently employed at different glass factories - over several issues in 1973 and 1974. The questions proceeded from the general to the particular: from the meaning of the medium (the expressive potential of glass and its role in shaping the environment) to individual creative goals, to the artist's relationship with production ('How do you manage to work both on unique pieces and on prototypes for mass production at the same time?'), to, finally, future plans and projects. The first question revealed the affective relation of an artist to his or her material: the intertwined recognition of its 'thing-power' and the will to master it. This dialectic was made especially vivid in the response by Adolf Kurilov, an artist at the famous Gus' Khrustal'nyi factory (Vladimir oblast): glass 'can be cut, moulded, faceted, etched, blown, engraved, glued, frosted, and fused with ceramics; one can paint over it with a brush and draw on it with carbide pencil ... It can be opaque, transparent, coloured and colourless. I do not know what other material has equal capabilities.' Glass 'intrudes' into the environment as 'boldly' as do wood, metal and ceramics, and can eventuate not only as dinnerware or windows, but as 'entire walls and skyscrapers'. Here Kurilov alluded to the strong utopianism of the Russian avant-garde, revived during the recent obsession with modernist clarity and transparency. 
Other responses feature more intimate and less 'corporeal' visions of the material: according to the Leningrad factory artist Aknunii Astvatsaturian, glass is an 'amazingly poetic material' that can take any form, while for the Moscow artist Svetlana Beskinskaia, glass was the medium for transmitting one's thoughts and feelings. ${ }^{39}$ Boris Smirnov, who was usually very attentive to the sensory qualities of glass, gave a strikingly anthropocentric answer: glass by itself is no more special than any other material, because it is always the artist who has the upper hand and who must stay 'above' the material.

When it came to the 'unique vs. mass-produced' dilemma, all the responses leaned towards some sort of compromise. For Kurilov, the design of mass prototypes was 'labour', while unique works were the expression of 'a soul singing'. When the soul is out of songs, an artist should turn to massovka (a rather pejorative term for mass production). So, according to Kurilov, mass production was not a noble duty but a constant obligation. He added, however, that production plans sometimes interrupt creative work on unique pieces, pressing an artist to resort to mass-producible prototypes. This would obviously mean silencing the singing soul. ${ }^{40}$

Other responses, though, were more positive towards prototypes for mass production. Svetlana Beskinskaia, the chief artist of the Glavsteklo (Main Administration of the Glass Industry) at the Soviet Ministry of Industrial Construction Materials and the secretary of the board of the Soviet Artists' Union, characterised the work of a factory-employed artist as a 'single, seamless process':

When working on a unique piece, I find new solutions for mass objects. The work on a mass object [massovoi veshch'iu] is a necessary training of creativity, and the rigidity of the factory conditions charges and activates the thinking. I consider production the best and only basis for the true tempering of an artist.

Using the popular term from the 1920s-1930s - 'tempering' (zakalka) Beskinskaia presented a modernised version of the myth of the New Soviet Person shaped by hard work and education. ${ }^{41}$ This argument, however, was less motivated by personal beliefs and more by Beskinskaia's status at Glavsteklo, which she headed in 1966 and wherein she initiated the 'Resolution on artists in the glass industry' that secured benefits for artists and gave them access to research trips. Dedicated to strengthening ties between artists and technical workers in factories, ${ }^{42}$ Beskinskaia needed to present industrial production as beneficial and even necessary for one's growth as an artist. She even stated that her dream was to find an end to the seemingly interminable debate over 'mass vs. unique'. Beskinskaia had belonged to the staff of the Diat'kovo glass factory (Briansk oblast). Her colleague at this factory, Viktor Shevchenko, seconded her opinion on the indivisibility of unique and mass-producible objects in design: 'I believe an artist who cannot establish good relations with production is also inca- 
pable of solving the simplest creative task.' Likewise, Stepan Moiseenko, an artist from an older generation at the Vosstanie factory (Chudovo, Novgorod oblast'), optimistically noted that what is unique today can become mass production tomorrow, claiming that he always worked on unique pieces with mass-reproducibility and broad availability in mind. ${ }^{43}$

A particularly noteworthy part of this discussion was the relationship between artists and industrial workers, who, possibly alluding to the 1920s, were often called 'productivists' (proizvodstvenniki). Many artists called for closer cooperation. Leida Jurgen, one of a cohort of Estonian artists who had joined the Leningrad Factory of Artistic Glass in 1955, argued that only a team of specialists from various professional backgrounds could successfully solve the problems of artistic glass production. The Moscow artist Vladimir Filatov called for building a relationship of artists with industry on the basis of 'mutual respect and understanding of [common] interests, aims and needs'. Smirnov, who worked in many different areas of art and design simultaneously, acknowledged glassblowing as the truest embodiment of creativity. He described his cooperative work with a glassblower as 'the most interesting: this is an exceptional opportunity to directly and naturally enrich art by incorporating the artistry of the glassblower, naïve and free, untouched by the informational chaos from different channels, from which an artist has no means of relief'. This romanticisation of a craftsperson's unalienated labour, free from the baggage of art theory, may be seen as condescending rather than respectful. However, it does make the glassblower more visible in the professional discussion. In her cultural history of glass in Russia, Julia Chadaga analyses glassblowing in new materialist terms, as a site of affinity between the human body and the material, of 'corporeal associations' that glass often produces. She cites the historian Isobel Armstrong who 'juxtaposes the invisibility of the glassblower with the unseen bubbles left in the glass as traces of the worker's breath, his presence'. ${ }^{44}$

For Smirnov, this corporeal presence of a glassblower, symbolically presented in his 1961-62 'Glassblower's triptych' (figure 3.2), was, in a way, superior to the intellectualism of the artist, but only in combination could the two be used to produce high-quality objects. Even though, as critic Alla Pavlinskaia noted, Smirnov always insisted that he was "not a glass artist but an artist' (ne stekol'shchik, a khudozhnik), he also was continuously fascinated by folk, amateur and 'primitive' art, as is apparent in his 1970 book Artist on the Nature of Things. ${ }^{45}$ In her article celebrating Smirnov's 70th birthday, Pavlinskaia regarded this alleged contradiction as a sign of his professional strength: 'The simplicity and naivety of folk art looks surprising in the works of such an intellectual artist. But this fascination is not accidental, and it is devoid of artificiality and stylisation, which are so frequently found in today's art. ${ }^{\text {'46 }}$ The embrace of folk simplicity 
made Smirnov's work, as it were, immune from the 'capriciousness' that alarmed quite a few art critics at the time.

After quoting factory artists who had participated in the 1973 glass show, Dekorativnoe Iskusstvo SSSR dedicated an entire issue (October 1973) to the problem of the mass production of household objects. This special issue was opened by an article by the VNIITE design theorist Leonid Pereverzev. The article began by asserting the importance of thing-power:

the ready objects, like all other products of human activity, gain relative independence and start living by their own principles. People have to comply with these principles as long as they have no possibility to change the structure of the artefactual world [veshchnoho mira] in the direction they find desirable and necessary.

However, Pereverzev went on, the structure of human-object interrelations depends on a complex network of factors, including individual and group identity, social status, and production conditions and economic goals. Moreover, while many artists were praising handicraft as more symbolically potent than mass production, only the latter can be the "main source of objects' in the contemporary world. While acknowledging the flaws of Soviet industry, which often refused to accept new prototypes, Pereverzev cautioned readers against blaming outright 'engineer-productionists' for the poor quality of Soviet goods. 'Instead', he suggested, 'we should ask if artists and designers recognise their share of responsibility for the deformation and de-aesthetisation of the contemporary artefactual world, and if they use all their knowledge, skills and capacities to solve this problem.' Readily assuming the role of a misunderstood genius, factory artists overlook 'the fundamentally different means of form-giving, hidden in technology'. Closer contact with engineers and 'dialogue and cooperation with up-to-date industrial technology' was necessary for artists and designers to make substantial contributions to modern culture, Pereverzev concluded. His article implicitly acknowledged thing-power not only as the (relative) self-sufficiency of objects-as-things, but also as the power of technology in guiding a designer. ${ }^{47}$

The following pages of the issue featured an editorial statement arranged in a 'ladder' fashion, akin to earlier avant-gardist manifestos and futurist poetry:

\author{
TODAY \\ THE TASK \\ IS FORMULATED \\ AS FOLLOWS: \\ TO INCLUDE THE MACHINE \\ IN THE CIRCLE OF \\ HABITUAL \\ ARTISTIC \\ MEANS
}




\author{
ALONG WITH THE BRUSH \\ THE CHISEL \\ THE POTTER'S WHEEL; \\ TO PROVE \\ THAT \\ A MACHINE-MADE \\ MASS-PRODUCED OBJECT \\ CAN BE \\ ON A PAR WITH \\ HANDMADE OBJECTS. ${ }^{48}$
}

As the editorial team explained following this statement, it refuted the common belief of artists that the production process 'spoils' their designs, arguing that the artist is not the sole author of the object - he or she shares this role with the factory directors, technicians and craftspeople. 'On the way to the consumer', the editorial explained, 'the object acquires new authors, who leave their imprint on it.' Perhaps unwittingly, the editors invoked the concept of 'the biography of the object' made by the avantgarde theorist Sergei Tretiakov in 1929: an object passing through the hands of a range of people acts as a measure of their collective emotions and the dynamics of social relations. ${ }^{49}$ A late socialist object was a product of a whole collective and a participant itself in cooperative labour.

The editorial's emphasis on how multiple authors leave their imprint on an object was also close to a theory proposed by the design historian Kjetil Fallan: an object's original script, devised by a designer, changes in the process of production. ${ }^{50}$ The notion of a script originally came from the sociologist Madeleine Akrich, who argued that designers 'inscribe' their vision of the world in the technical content of objects they design. Fallan suggests not limiting 'script' to technical content, but rather seeing it as the designer's intentions, including 'utilitarian functions, aesthetic expressions, social meanings and cultural identities'. Thus understood, the script does not define the object for its entire lifespan: 'there is always the chance that the actors do not play the role the designers ascribe to them' ${ }^{51}$ Fallan further discusses mediation and consumption as the sites where the script undergoes changes and challenges. The articles in Dekorativnoe Iskusstvo $S S S R$, however, suggest that, even before an object reaches the retail trade its script is significantly modified by technicians and engineers. Those workers, the editorial team wrote, do not try to take away authorship from decorative artists and designers, but instead would name industry as the real author of objects. ${ }^{52}$ In this understanding, the power dynamics of the factory unfold between non-human agents: industry, enforced by modern technology, produces objects for mass consumption, while people from different professions should adjust their plans and ambitions to this process. More precisely, modern industry here plays the twin role of tool and guide. Accordingly, rather than sticking to the pitiful position of a 
misunderstood genius, the decorative artist or designer should modernise their attitudes to see the machine as their main instrument and the whole of industry as their workshop. Industry would then be able to 'understand its goals aesthetically', moving past simple production quotas to manufacture objects that would comprise the real world of high-quality goods. ${ }^{53}$

To illustrate their argument about the central role of technology in shaping objects of mass consumption, the editorial staff of Dekorativnoe Iskusstvo SSSR went into production, collecting joint interviews with artists, administrators, engineers, technicians and craftspeople. The first published interview related to glass - the material that had been in the spotlight in art and design criticism and was at the forefront of new design tendencies. Svetlana Beskinskaia, the chief artist at Glavsteklo, spoke with Boris Pozin - Glavsteklo's deputy director and the head of the Planning Department at the USSR Ministry of Industrial Construction Materials - on behalf of Dekorativnoe Iskusstvo SSSR. Noting that glass production was developing exponentially and that the number of factories was growing, Pozin emphasised that the goal of the Soviet glass industry must be to produce more goods 'at a high artistic level and in a single aesthetic mode'. To achieve this goal, factories must provide artists with time slots for 'personal creativity', so that they can work on unique exhibition items and thus polish their skills and be more efficient for mass production. Though she lauded Pozin's intentions, Beskinskaia objected that participation in exhibitions, domestic and international, was by no means a 'personal' affair. She argued that exhibitions provided great opportunities for professional networking and the exchange of knowledge, which is as necessary for artists as their 'daily bread'. In addition, travelling to exhibitions gave artists the opportunity to root around local home accessory stores and become more familiar with the realities of markets and retail at home and abroad. Welcoming these provisions, Pozin also suggested dedicating the meetings of the Glavsteklo Artistic Council not merely to assessing prototypes but also to discussing the current agenda with artists and engineers: 'opinions will clash, and [thereafter] contacts will solidify'. Here, at Glavsteklo, art and industry seemed to achieve a blissful union, with all the agents of production working in harmony. ${ }^{54}$

However, despite these discussions, Dekorativnoe Iskusstvo SSSR portrayed an image of the artist in production that was far from saccharine and propagandistic. The editors admitted that, in practice, the relationship between the artistic collective and the administration at a factory could be painful. For example, at the Konakovo faience factory, an old centre of the ceramics industry in the Tver region, 90 per cent of the products consisted of crude dishware with primitive decoration, hand painting had been almost abandoned, underglaze painting had been almost totally discontinued, and faience figurines had completely disappeared. As a result, this previously renowned factory had nearly lost its artistic reputation. 
Asked by the journal for the reasons for such failures, the deputy director Anatolii Likhotnikov simply responded that the factory had 'more important things to care about than artistry' - namely, an urgent need to satisfy the market with practical crockery. Sophisticated decoration methods slowed down production, and so the factory's administration had its artists designing patterns for stencils and stamping. 'We work in a large enterprise, not at an experimental factory', he reminded Decorativnoe Iskusstvo SSSR, 'therefore let the artist not be offended when I call them factory workers the same as everyone else. We work to supply the population with crockery.' In light of the chronic failure of Soviet crockery production to meet demand, Likhotnikov's arguments sound reasonable rather than arrogant. The common practice of crockery producers in the 1960s had been to produce labour-intensive, lavishly decorated objects, which would have been more expensive. Since the planned production value was set in terms of retail price, it was easier to fulfil by producing fewer expensive goods than a large amount of more affordable and practical ones. As a result, crockery factories technically fulfilled production requirements, but in reality expensive items remained unsold in warehouses. ${ }^{55}$ Compared to this practice, Likhotnikov's attitude seems to have had a healthy dose of pragmatism, as did his treatment of all factory employees as equal in decision-making. The wider mechanisation of production processes, the replacement of crucibles with tunnel kilns and the introduction of stamp machines, he stated enthusiastically, enabled them to produce 109 million items per year.

Here, however, the artist from the Konakovo factory, artist Nikolai Kokovikhin, stepped in to contradict Likhotnikov, suggesting that mechanisation lowered the quality of goods and, hence, their saleability. Their product was failing to meet 'elementary artistic requirements'. The objects that were accepted as prototypes for mass production in the 1960s, when Kokovikhin joined the factory, would now be dismissed as too complicated and only feasible as unique exhibition pieces, a lowering of standards obviously harmful to the factory. No urgent tasks and targets, he insisted, could justify the neglect of experimental, creative work, which was not an indulgence of artists but the 'avant-garde of production'. Prioritisation of production goals marginalised creative work by reducing artists' tasks to devising stencils for standard decoration. Another important problem was the shortage and overburdening of patternmakers. Moreover, Kokovikhin complained, the USSR lacked special schools for patternmakers, engravers and painters for the ceramics industry, and these professions were gradually disappearing. As for the modernisation of technology, it was done at the expense of quality: tunnel kilns could not compare with crucibles in firing experimental pieces. Furthermore, even new machines, such as the English Murray Curvex for decorating flatware rims, could not be used to its maximum capacity because of a lack of high-quality dyes and 
binders and, again, the shortage of properly skilled technicians. Clearly, while for the administrator the main bottleneck of production was artists' undue focus on 'individual' creativity, for the artist it was a neglect of professionalism coupled with the technical deficiencies of the factory. ${ }^{56}$

A similar polemic over the role of technology in the development of decorative art unfolded between Liubov' Pavlova, the senior engineer at a leading metal kitchenware factory, and the VNIITE theorist Evgenii Shchedrin. While Pavlova expected an artist to be a 'technologist' - in the sense of someone who learns and adjusts to existing technology Shchedrin believed that an artist should be ahead of technology in order to satisfy the needs of consumers, not the requirements of the industry. Experimental work should be the driving force for updating technology, he argued, and production plans should include small experimental pressruns that would lead the way for technical modernisation. The editorial approved of this proposal: if currently new compositional suggestions from an artist-designer, which demand the reconstruction of technology, often hamper the fulfilment of the big industry's economic targets, special experimental forms may reveal the factors for stimulating and improving the technology of industrial production'. Small experimental series, they concluded, could facilitate many of the issues where artists and industry needed to compromise and find mutual understanding. Should that become reality, the debate on what should lead - art or technology - would become irrelevant. ${ }^{57}$

The critic Nikita Voronov further developed this proposal. According to him, the key problem in the relationship between artists and factory administrators was a mismatch of priorities and even jealousy. Artists often joined the factory at the start of their career and used the opportunity to take part in exhibitions and research trips as much as they could, provided by their employer. If an artist demonstrated both talent and networking skills, he or she would receive commissions for unique artworks for public interiors and would be allowed to go abroad as a part of the Artists' Union delegations, and receive publicity in mass media - in short, increasing the artist's social capital. For the factory administration, the success of the factory's artist could mean that they became distracted from production goals, and so the employer would have to cut down on the artist's time for research and creative work, participation in exhibitions and bonuses. Thus, the conflict between artist and administrator was not only economic and disciplinary but also psychological. Voronov referred to it as the opposition of 'the two structures of consciousness': one 'notional' and 'scientific-technological', another 'impressional' and 'artistic'. This clash, he argued, could be resolved in 'production culture': the organisation of workflow to prioritise the continuous updating of the variety of goods. ${ }^{58}$ Such a production culture implies that artists focus not on style, but on the adequacy of their designs to changing daily lifestyles. For example, 
rather than designing a mass-produced imitation of faceting for a drinking glass, an artist should consider whether people in the future will need drinking glasses at all. To reach this prognostic sort of thinking, the factory needs 'mediators' between artists and engineers: sociologists, merchandise experts and 'object researchers [veshchevedy], specialists on material culture' ${ }^{59}$ Based on research and perfect organisation, future-oriented and interdisciplinary, the production culture envisioned by Voronov guaranteed the steady and constantly changing stream of comradely objects.

\section{Talkative things}

A new 'production culture' that would finally act on the 1920s productivist vision of the role of the artist in a socialist society was one scenario promoted by Dekorativnoe Iskusstvo SSSR on behalf of the professional community. Alongside it, critics continued to develop the idea of a soon-to-be hybrid form of material culture that would incorporate decorative art, easel art and design. These discussions tended to move away from production and consumption, focusing instead on the formal, sensory and 'spiritual' qualities of objects. Critic Nikita Voronov himself spoke of the progress 'from pure form to image' in decorative art shown at exhibitions. ${ }^{60}$ In this process, he noted, the critics' favourite material, glass, was ceding its leading role to ceramics. While some artistic experimentation had already occurred in this material before, ceramics was now witnessing 'the birth of something new': a 'non-canonical attitude to the determinants of decorative art - material, colour and form'. Symptomatically, in the spring of 1972 a group of young artists worked together on an experimental project at the Moscow Experimental-Creative Production Centre under the guidance of Adrian Bortsov. The resulting small exhibition and the participants' later appearance at the all-Union Young Artists' show and the Soviet Russia exhibition demonstrated a striking novelty. The diversity of the exhibition was, for Voronov, an advantage: some artists emphasised the material, presenting objects that were 'ceramics to the core', others demonstrated painterly and sculptural qualities; some artists focused on colour in their works, others emphasised spatial relations. All of this did not signal eclecticism, but rather progress towards a new synthesis of art that allowed for a multiplicity of combinations: 'painterly plane combines with relief and volume, sculptural volume with spatial colour, and natural thingness [natural'naia veshchnost'] with illusory space'. ${ }^{61}$ Apparently speaking of this new synthesis, Voronov referred to the material environment of late socialism beyond the factory floor, shop windows and prefabricated flats.

The impulse for 'synthetic' and non-utilitarian ceramics came, unsurprisingly, from the Baltic region, which since the 1950s had set the tone for Soviet decorative art. In 1971 Vilnius was the first Soviet city to host the All-Union Symposium of Ceramic Artists (the first such conventions of 
ceramic artists had been held in Austria in 1965, and in Czechoslovakia in 1970). Organised by the Artists' Union of the Lithuanian Socialist Republic, the event brought together thirty artists from various Soviet republics and fourteen representatives of Soviet bloc countries, plus Vietnam and Mongolia. The symposium's theme, 'national traditions in Soviet ceramics', did not result in simple, formulaic salutes to the 'truly people's character of Soviet art', but in an eager exchange of ideas and technological know-how. For a month, the artists worked in ceramics workshops, visited traditional craft centres, talked to each other and to journalists and critics, and produced altogether 400 objects collectively. Many of these objects defied traditional ideas of what ceramics should be and featured abstract and fantastic forms reminiscent of folk clay toys, sculptures by Constantin Brancusi and ceramics by Picasso all at the same time (by 1971 Soviet artists were familiar with all of these sources due to greater access to professional literature and trips abroad). ${ }^{62}$

The Vilnius symposium was held for a second time in 1975, again with a great diversity of participants in terms of geography, age, professional credos and approach to material. According to the artist Juozas Adomonis, one of the initiators of these events, both symposia responded to international trends in studio ceramics while also demonstrating the specific styles of national and regional schools in socialist countries. Reviewing the collaborative summary exhibitions in his 1976 article, Adomonis used the term 'decorative author ceramics' (as opposed to 'household ceramics') and pointed to its relation to 'high art'. He argued that at the symposia of 1971 and 1975, 'applied-art qualities receded to the background, while the focus moved to emotional and metaphorical content, to the spatial, or, one can say, "architectural” qualities, and to not narrowly utilitarian, but the plastic nature and decorative functions of clay objects' ${ }^{63}$ Accordingly, the final discussions at the symposia announced that the traditional criteria of decorative art were obsolete, reiterating the late 1960s polemics on neodecorativism. Now, critics and artists were to learn 'to evaluate the spiritual qualities of ceramics, its connection with easel art and architecture, its new content and new beauty, its capacity to integrate to architecture'. Thus, if in the late 1950s to early 1960s the equality of easel and decorative arts was justified by the latter's practical usefulness and omnipresence in the home, now decorative art aspired to be 'big' due to its ability to achieve diverse visual effects either through or in spite of medium-specificity, and to tackle complex philosophical questions.

At the same time, Adomonis advocated preserving ties with the handicraft aspect of ceramics. Notably, many symposium participants did not stop at the design stage but worked through the entire production process, learning from craftspeople. Practical training in ceramic craft must be included in the curricula of all art and design schools, he argued, because artistic individuality should be embodied in the materiality of an object, 
in the particulars of its making. In this respect, ceramics could be at once boldly innovative and perpetual: "however saturated our daily life becomes with objects made from synthetic materials, however convenient, simple and cheap they are, people will always be drawn to crockery, to a vibrant object that reflects a thousand-year-long history and that preserves the spirit of handicraft, the folk spirit'. ${ }^{64}$ Though he greatly understated the age of ceramics, Adomonis did make a good point regarding the artists' effort to synthesise tradition and modernity by creating a particular Soviet version of studio craft - the state-supported professional activity that aimed not to improve mass consumption but to reimagine ceramics in dialogue with the long tradition of the craft.

By the mid-1970s, the discussion of spiritual qualities, symbolic meaning and the expressive materiality of decorative art had become widespread. Critics, artists, designers and architects questioned the simplistic principles of socialist modernism. Their discussion generated a new theme: the talking (and 'talkative') object. Historian of science Lorraine Daston notes that, historically, things (the term she prefers) speak in two diametrically opposing ways: as idols (when they manipulate and deceive) and as evidence (when they demonstrate and testify). But this opposition, Daston argues, is misleading: both extremes 'appear to work by the same mechanisms of reversal and replacement', so that a copy may appear more authentic than the original, and an object's ability to speak the truth may in fact be a lie..$^{65}$

The talking objects which were shown at Soviet exhibitions in the 1970s seem to have functioned in neither of the two modes described by Daston. Instead, these objects engaged in an intimate conversation with the viewers, where truth was less important than confidence. The objects shown at Khrushchev-era design exhibitions, like the famous 'Art into Life' in 1961, claimed to be true to their materials and to their intended, practical purposes. However, they could reach homes only through ministerial and factory bureaucracy, impeded by rigid planning and poor supplies of raw materials, as poor embodiments of original designs. Disappointed in the idea of the 'honest objects' of the aesthetic turn, critics and artists now placed value on objects that would not necessarily be simple and practically functional but could offer quiet reflection, awe and a feeling of intimacy. For example, the exhibition of sixteen young decorative artists (half of them women!) in the Yelagin Palace Museum in Leningrad, held in the winter of 1973-74, impressed the public with its subtlety. One critic characterised the exhibits at the Yelagin Palace show as 'shaded and soft-spoken', 'talking to the viewer confidently, in warm and soft tones, sometimes jokingly'. Objects such as the chamotte plate by Olga Nekrasova-Karateeva, decorated with the Cezannesque landscape of Leningrad's Summer Garden, and the campanile-shaped ceramic sculpture by Mikhail Kopylkov, aspired to act as intimate friends to the viewer, not as comrades who call loudly 
to propagate new visions of everyday life. ${ }^{66}$ Because of their affinity with easel art and complex imagery, these objects contrast with the massproduced ceramics of the time that often demonstrated a continuity with the geometric forms and minimalist abstract decorations of the 1960s (plate 12).

The artists' growing preference for 'quietly speaking' objects may sound like a typical manifestation of the Brezhnev-era state-sponsored embrace of domesticity as an antidote to political discontent - what Natalia Chernyshova calls the 'Brezhnev-era domestic counter-revolution'. ${ }^{67}$ However, the trope of a 'talking object' stemmed from artists' growing tiredness with the state campaign for socialist consumer culture. To be sure, in 1976 the government accepted the proposal of the Artists' Union and the Academy of Arts of the USSR to issue 'Regulations on artists in industry' that broadened the power of factory art directors in decisionmaking and thus raised the status of artistic personnel. ${ }^{68}$ However, factory artists still refused to dedicate the majority of their creativity to mass production. Likewise, the artists who were affiliated with the Art Fund and worked under contract from state commissioners sought opportunities to release their creative drive without restraint. The mid-1970s thus witnessed a strong effort by decorative artists to create oases of freedom in the system of exhibition committees and factory production plans. Obviously, the state could effectively utilise this effort to broadcast an image of a happy and unrestrained artistic life under socialism by exhibiting the most interesting experimental works of decorative art abroad. Therefore, Soviet decorative artists' international networking grew exponentially in the 1970s. ${ }^{69}$ The artists, in turn, used this cynical support of the state as much as they could in order to catch up with the international development of studio craft.

So, what did Soviet decorative art in the 1970s 'talk' about? The most successful attempt to decode the messages of the artworks produced at this time was probably the young art critic Margarita Izotova's, in her contribution to a 1978 edited volume on the mid-decade state of affairs in Soviet decorative art. ${ }^{70}$ The stylistic unity of the late 1950 s to early 1960 s had ended completely, she argued, as had the belief in a 'paradise dense with artefacts [opredmechennyi rai]', the door of which was supposed soon to be unlocked. As it turned out, the 'contemporary objects' were becoming not simpler but, instead, more complex and enigmatic. As Izotova noted, the artists' common interest in the construction, material and spatial nature of objects had nearly faded, because these concepts had become overused and trivialised. Even decorative art's relation to architecture, seen by other critics as one of its distinct features, was, for Izotova, negative: objects stood out as antagonists to enduring architectural modernism. Harmony was no longer an ideal, and elementary sensory qualities of materials were no longer sufficient for making a statement: 
If yesterday an accidental streak of glaze, the natural structure of wood, or a drop of glass were regarded as aesthetic discoveries, and we thought that the author should just help to reveal the force of nature; if a prism, a cone, and a cylinder were so convincing in their formative value that we looked at the world through them, then today all the rhythms have been dispersed and complicated. Links between objects have lost the clarity and simplicity that now seem primitive. Our consciousness is now looking for deep and subtle conflicts, and the formal unity and elusive, seemingly sufficient harmony of the architectural-artefactual environment cannot satisfy us any more. ${ }^{71}$

1970s Soviet objects, therefore, became talkative - or, rather, chatty - for a reason. Their quiet monologues signalled their refusal to integrate into plain, modernist environments where one needs to speak loudly to be heard. Izotova pinpointed the theatricality of new decorative art as a mode to create multiple scenes, each with its own 'micro-climate' that was indifferent to the whole. Such scenes could emerge at the level of exhibitions or single artworks. One group of ceramic artists in Leningrad made an effort to create such an alternative order of Soviet things.

\section{'Image-ceramics' by the One Composition group}

In the bright early springtime of 1977, in a small hall of the Leningrad Artists' Union, opened an exhibition with the light musical name 'One Composition' that would resound as a call for freedom for several years. There was no crowd, but not a small number visited this hall, walking among the podiums with 'ceramides' that were 'useless' as never before and incompatible with 'common sense'. People would go there to think, laugh, marvel and ponder over the intricate puzzle in which life captured us at that time. Odd clay things grew on white plywood oases; these things sprawled, then arranged themselves in elegant lines, only to suddenly fall to pieces. ${ }^{72}$

This is how Margarita Izotova recalled the first public event organised by a group of young Leningrad ceramic artists. This group was inspired by the Vilnius symposia and the 1973-74 Yelagin Palace exhibition. From 1977 to 1986, roughly twenty artists were exhibited together informally at the premises of LOSKh - the Leningrad branch of the Artists' Union of the Russian Soviet Socialist Federal Republic (RSFSR). Each could present only one work, so both the group and the exhibition series took the name 'One Composition' (Odna kompozitsia, or OK, as it was sometimes abbreviated). One of OK's core members, Mikhail Kopylkov, describes it today as more than just a decorative art show; it was a gathering of 'free artists' who approached ceramics as visual art and used this material as a medium for transmitting their ideas. ${ }^{73}$ Indeed, the group's main objective was to take refuge from the design of commodities and focus on the formal, plastic and symbolic aspects of form-giving. They termed their pursuit izokeramika ('image-ceramics'), as opposed to pottery. 
However, the idea of 'free artists' hardly reflects the genesis and practical basis of the OK exhibitions accurately. The group emerged within the institutional system of Soviet decorative art and relied on the material supplies and technical labour that the system provided. Kopylkov himself, in his history of $\mathrm{OK}$, co-authored with Izotova, admits that the system of workshop cooperatives (kombinaty) and Houses of Creativity, supervised by the Soviet Art Fund, provided the material foundation for izokeramika. These institutions were, in the words of Izotova and Kopylkov, 'birthing homes' for modern ceramics in many Soviet cities. As they explain, the state budget for major construction works included funds for so-called sotskul'tbyt ('social, cultural and everyday facilities') - fittings and interior design. The surplus from this funding was spent on commissioning various artworks from decorative artists affiliated with the Art Fund. These payments constituted the financial basis of the Artists' Union of the USSR and covered, among other needs, the work of the kombinaty and the Houses of Creativity, staffed by administrative and technical personnel to help the artists realise their experimental designs. This practice of 'indirect financing of art spheres located at the periphery of ideological control' was beneficial for the development of cutting-edge trends. ${ }^{74}$

The major production site for the OK group was the experimental workshop at the Kombinat of Decorative-Applied Art at LOSKh, founded in 1965 by the art historian Maria Zelentsova, who was also its first director (and consistently advocated for the interests of decorative artists in the Artists' Union and the Art Fund of the USSR). The experimental workshop attracted artists not affiliated with ceramic factories but who were working on commissions through the Art Fund, most of them graduates of the Department of Artistic Ceramics and Glass at the Mukhina School. Recent graduates could work at the LOSKh workshop side-by-side with experienced artists, while the absence of market competition allowed for the sharing of design techniques and concepts. This collective mode of working compromised the usual notion of authorship, as it was often difficult to identify the person behind a particular piece made in the workshop. Since ceramic departments at Soviet art schools did not train students in the practical drudgery of ceramics (preparing ceramic mixtures, glazes, dyes, building kilns and managing baking temperatures, and working on the potter's wheel), the Art Fund's workshops employed potters, technicians and tool-makers to implement the designs. The dependence of artists on potters further eroded the borders of authorship. Even if an artist refused to be just a 'paper ceramicist' (to use Adomonis's expression) ${ }^{75}$ learning all the technical processes and going through all the stages of production, he or she still needed the guidance of technical workers.

The Baltic region, too, played an important role in providing material preconditions for izokeramika. In the 1970s the House of Artists' Creativity (the state-sponsored residential art centre that had existed since 1945 in 
Dzintari, a neighbourhood in Jurmala, Latvia) became the centre of Soviet experimental ceramics. A special commission from the administration board of the Artists' Union of the USSR attended the regional exhibition and decided which artists were worthy of participating in the yearly symposium in Dzintari. Being selected was considered to be a great honour. Konstantin Rozhdestvenskii, the leading Soviet exhibition designer and student of the famous avant-garde artist Kazimir Malevich, played a significant role in the selection process and actively supported experimental ceramics. ${ }^{76}$ The two-month-long symposium in Dzintari gave the artists access to intra-Soviet networking, to developments in Western studio ceramics, and, in terms of technology, to the use of high-temperature wood- and oil-fuelled firing (as opposed to low-temperature firing in the Leningrad workshops). As Kopylkov and Izotova explain, Latvian artists demonstrated their know-how, such as using soft clay strata pressed with cloth. They "generously shared their experience of achieving different surface textures [faktura], salts and oxides of metals [for decoration] and other handicraft techniques, hitherto little known or unknown by Eastern colleagues until the early 1970s'. ${ }^{77}$

Furthermore, the exhibitions that ended the symposium were also attended by the Moscow-based committee who selected the best works for participation in the International Ceramic Competition in Faenza (historically home to majolica-ware that gave it the name 'faience') and at the International Ceramics Biennale in Vallauris (the home of Picasso's studio ceramics). While the Soviet presence in Vallauris was mainly extramural, the Faenza event welcomed Soviet artists personally at the insistence of Count Edmondo Marabini, an art critic and the key organiser of the competitions, as well as a communist and lover of Soviet culture. ${ }^{78}$ Thus, Dzinrati was a window to the West for the Leningrad artists who later formed OK.

Both production bases - the Art Fund's Kombinat with its experimental workshop and the Dzintari symposium - provided a postgraduate education for young Leningraders and furthered what the art historian Julia Gusarova calls the 'Leningrad school of ceramics'. Referring to Russian art theorists, she defines 'school' as a complex system of training artists, including formal institutional curricula, work experience and informal networking, as well as the practical realisation of this system's principles in artworks. The Leningrad school of ceramics was strongly defined by the Department of Artistic Ceramics and Glass that emerged through the conjoining, in 1955, of the Departments of Architectural-Decorative Ceramics, headed by Anatolii Mikhashevskii, an expert in ceramics technology, and the Department of Artistic Glass, led by the famous Boris Smirnov. ${ }^{79}$ Upon the unification of the two, the new department was headed by the charismatic architect Vladimir Markov, who, like Smirnov, belonged to the cohort of the Architecture Department of the Ilya Repin Institute ${ }^{80}$ that had been unwilling to partake in Khrushchev's prefabricated construction 
campaign. As one of the leaders of OK, Vladimir Tsivin, recently recalled, Markov consistently spoke of the architectural nature of ceramics and urged students to approach designing a tea set in the same way as designing an architectural ensemble, arguing that the architectonics of useful objects influences the surrounding architectural space. ${ }^{81}$

Though the department had several strong specialists trained as architects, both women and men, its graduates singled out Vladimir Vasil'kovskii as Markov's counterpart in guiding the students. While Markov gave predominant attention to the plastic qualities of clay and work with expressive form, Vasil'kovskii favoured figurative imagery inspired by St Petersburg's architectural heritage, classic Russian literature and foreign literature, finde-siècle Russian symbolism, Greek and Roman antiquity and Russian folk art. Tsivin views the contrast between Markov's and Vasil'kovskii's artistic credos - rationality, abstraction and adherence to rules versus emotion, a penchant for vivid figuration and an urge to break the rules - as the key factor for the successful development of the department. One charismatic leader only has epigones, whereas the tension between two creative personalities provokes independent thinking, Tsivin argues. ${ }^{82}$ Notably, this vision was informed by the cult of the male genius that was generally strong in late Soviet culture, particularly decorative art, despite the officially proclaimed gender equality and widespread presence of women in creative professions. Even though OK included several women, there were only half as many women as men. The gender politics of these late Soviet intelligentsia circles is a topic worthy of its own study. It is also notable that the majority of OK graduated from and/or taught at the Mukhina School.

Women, however, played a key role in starting OK. While Maria Zelentsova helped to secure workshops and equipment for ceramic artists in the Art Fund system, the tapestry artist Natalia Eremeeva came up with the idea of holding informal exhibitions displaying ceramics considered 'too daring for official shows', in the so-called 'Blue Hall' in the LOSKh headquarters. This initiative was a part of the 'intersectional club' at LOSKh, formed in 1976 as a forum for internal discussions and events. Responsible for the club's programme, Eremeeva considered ceramics to be the most advanced and critical area of Leningrad decorative art and proposed a regular, uncensored ceramics exhibition - on the condition that it would not be advertised and kept as a strictly internal affair. ${ }^{83}$ The resulting first exhibition in 1977, however, soon became known to Leningrad artists of many different backgrounds and even the broader circle of creative intelligentsia. Nineteen young artists - most of them in their early 30s - could contribute to the show, the only requirement being that the works had to have a non-utilitarian character. Vladimir Gorislavtsev, Nina and Aleksandr Gushchin, Aleksandr Zadorin, Mikhail Kopylkov, Olga Nekrasova-Karateeva, Natalia Savinova, Vladimir Tsivin and, later, Natalia Rotanova and Vasilii Tsygankov constituted the core of 
the group. They invited Vasil'kovskii, an older artist, to join as a revered intellectual leader. Other inspirational figures, such as Anna Leporskaia and Nina Slavina, long-term employees of the Lomonosov porcelain factory, as well as Boris Smirnov, were not invited - the OK group presumed that these celebrated artists would not be interested in such an odd initiative of a younger generation. ${ }^{84}$ Unlike senior porcelain artists, the members of OK considered porcelain to be a more traditional material and less open to experiment. ${ }^{85}$

These objects exhibited by OK had to differ substantially from the prototypes designed within contemporary 'production culture'. For the entire decade of its existence, the group persistently departed from the framework of consumer culture, even though quite a few of its members were or had previously been employed in factories and worked in mass production. OK functioned as a refuge - both from censorship and from the pressure of the planned economy. For example, in 1976 Vladimir Tsivin had just finished his four-and-a-half-year employment at the ceramic factory in the Siberian town of Bogashevo, Tomsk oblast. Now affiliated with the Art Fund's Kombinat, he considered the improvement of daily life a 'petty utopia' and wanted to create 'useless objects' - at least, so he remembers it today. ${ }^{86}$

Initially, OK emphasised materiality. In the group's manifesto, the artist and critic Grigorii Kapelian stated:

The oldest of crafts - ceramics - was born at the moment when the dumb primary consciousness developed a sympathy for three elements - earth, water and fire, when human beings started to deeply feel the life of clay that they aroused [...] Later, creating the myth of their origin, people handed to God nothing else but clay as the only imaginable material for moulding the first human being. We are very far from the time when art coincided with the craft of survival. Industry emancipated (or alienated?) human hands from the direct material production of utilitarian objects. But ceramics, as before, remains the art that gives an artist access to the creative mystery of nature, to the basics of the creative element in a human being. Ceramics is not sculpture even though sometimes it can play this role. The origin of ceramics is a vessel, that is, the thing itself, not its depiction. ${ }^{87}$

Though this mythologising was intended as an introduction, it was in effect a conclusion, because they moved away from the ancient tradition of pottery where the material used determined the finished product. OK was bidding farewell to the utilitarian object, the vessel. The exhibition poster, which Kapelian designed to complement the manifesto, depicts a pot with a stitch, as if it were a textile, or a once-broken and then awkwardly repaired thing. The first OK show in 1977 displayed a porcelain vase by the celebrated artist Vladimir Gorodetskii in a glass case separated from the rest of the exhibits, as a beautiful relic - a tribute to the recently and untimely deceased artist. The traditional object symbolically passed 


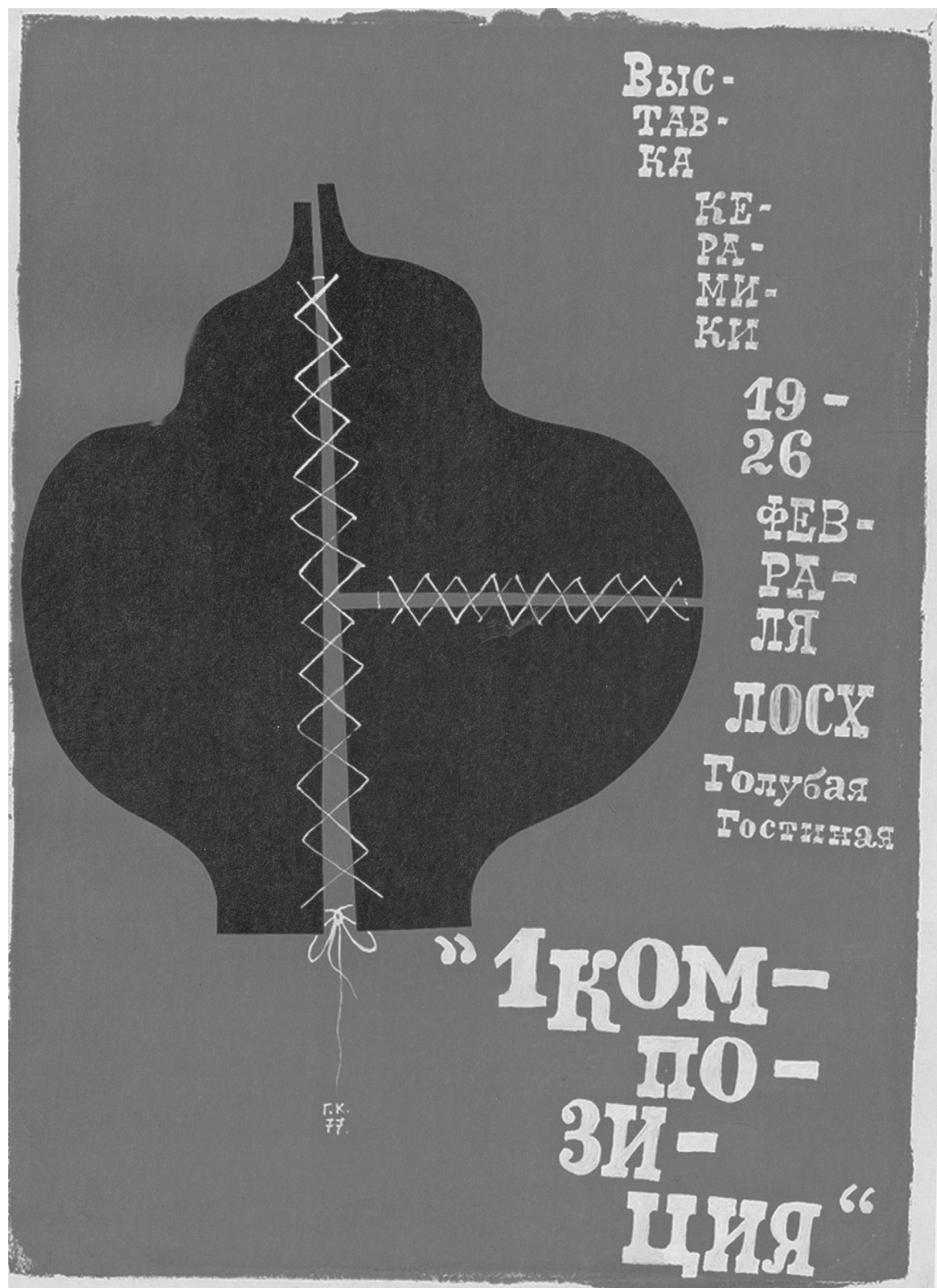

All rights reserved and permission to use the figure must be obtained from the copyright holder.

5.1 Grigorii Kapelian, sketch of the poster for the 'One Composition' exhibition, 1977.

away together with its creator; the status of avant-garde now belonged to izokeramika. The exhibition logo, a figure of a departing pot-seller, borrowed by Kapelian from a sixteenth-century etching by the German artist Franz Hohenberg, also symbolically acted as a point of departure. As 
Kopylkov later remembered it, 'the seller was removing the pots from the Blue Hall'.

What OK offered was what I call non-commodities - objects defying commodity form. For example, at the debut OK show in February 1977, several artists used the physical qualities of different types of clay to imitate structures, colours or shapes of natural things. One of the youngest participants, Vladimir Tsivin, presented the composition 'Autumn', made in the Bogashevo factory: amphorae of different sizes, covered by shiny ochre, dark red and grey glazes, arranged on latten brass sticks. The artist explains that he was inspired by the unusually warm Siberian autumn of 1975 and viewed 'foliage as amphorae turned upside down and hills as vessels resting on their sides'. Instead of painting this landscape, he sculpted it in ceramics, following his ambition to render 'all the colours of the beautiful Siberian autumn' through antique vessels. ${ }^{88}$ The resulting objects look multivalent - not just leaves and hills, but also rocks, fossils, or even reptiles of some kind. This effect could be achieved by different techniques. For example, the works of Olga Nekrasova-Karateeva and Nina Gushchina - 'Winter Morning' and 'Calla Lilies', respectively - emphasise the interplay of light and shadow rather than volume; they gravitate towards relief rather than sculpture in the round. NekrasovaKarateeva's work was probably inspired by lessons in Cezannist and Cubist painting that she had taken with the porcelain artist Anna Leporskaia, a student of Malevich (plate 13). ${ }^{89}$

Along with 'bio-plasticity', OK challenged the commodity form by what the critic Margarita Izotova called 'portraying ordinary objects', that is, mimesis of the everyday forms and textures of non-ceramic materials such as textiles, leather, metal or plastic. According to her, the artists were enchanted by the appearance of real objects and by the magic of mimesis, and could thus see the world anew and "erase the conventional border between art and non-art'. ${ }^{90}$ Kirill Makarov described this phenomenon with a different genre metaphor: 'Animation of lifeless matter, of habitual everyday objects - chairs, armchairs, lamps, lanterns and irons - has become widespread. A still-life attitude to the world Inatiurmortnoe otnoshenie $k$ mirul now predominates. ${ }^{91}$ Both critics carefully avoided the obvious comparison with Pop-art. However, they probably believed that the Soviet imitation of things was of a different nature: not an ironic or critical commentary, but an attempt to create dialogue between different materials, to question the difference between the tangible and the visible, to reveal the vibrancy of what is habitually perceived as nature morte.

The most famous example is probably Mikhail Kopylkov's contribution to the first exhibition, the composition 'Pink Dress and Autumn Coat', produced in Dzintari (plate 14). To make it Kopylkov employed the technique of pressing a stratum of chamotte (calcined fireclay) with cloth to reproduce the texture of clothes covered in autumn leaves (evidently this season was 
especially inspiring for ceramic artists). As Gusarova observes, although this composition (like Kopylkov's other works) is comparable to sculpture, he works with the material in a specifically 'ceramic way': not building the volume as in classic sculpture but shaping the material at once inwards and outwards. Therefore, what may look like a Pop-art-ish imitation of another material, textile, is actually the result of chamotte's plastic potential and its interaction with cloth that made it a form-giving tool. However, the composition also depicts gendered objects, reflecting late Soviet gender hierarchy constructed and seemingly 'naturalised' through commodities. The dimensions of these objects $-111 \mathrm{~cm}$ high for the dress, $116 \mathrm{~cm}$ for the coat - reinforce this impression. Thus, we see the interplay of different materialities: of chamotte, of actual cloth and of simulated fabrics, and the gendered bodies that these fabrics are supposed to cover. As an artwork, 'Pink Dress and Autumn Coat' is immune to changes of fashion. Like Oldenburg's Typewriter Eraser in Bill Brown's analysis, ${ }^{92}$ Kopylkov's 'clothes' are removed from fashion, consumption and craft, and 'elevated' to 'high art'.

Portraiture became an increasingly important theme in OK's exhibitions: the artists used ceramics as the medium to reflect on their everyday interactions with other people and with objects. The latter type of reflection was most vivid in Vladimir Tsivin's 1980 composition 'People and Objects' (chamotte, slipware, glaze, metal, wood and glass; produced at the Kombinat of decorative-applied art, Leningrad). Formally, it is a sculptural composition of three streamlined figures from the hips up holding seemingly random objects: a girl with a hula hoop, a boy with a magnifying glass and a featureless man with a ladder (plate 15). The first two objects represent the tools of late Soviet gender socialisation: hula-hooping was considered a proper pastime for girls, while setting fires with a magnifying glass was a popular, though reproachable, activity for boys. The symbolic meaning of the ladder is quite transparent too: the connection between earth and heaven, a difficult path towards perfection, or, more particularly, an artist's personal and professional development. The combination of these symbols gives wide room for speculation. The artist himself recently explained the essence of this work to be a contrast between stylised human figures and realistic, ready-made objects. One might further say that they act like protagonists, defining human activities and choices.

For Tsivin, however, what matters most is not the objects but the space they organise: 'they draw the border of space, the volume of air that belongs to the sculpture, captured by it'. ${ }^{93}$ Objects define the direction of people's gestures, and the potential trajectory of these gestures - turning and bending of heads, movement of hands - 'charges' the space and makes it 'a field of forces'. Therefore, the artist concludes, 'this work is about people and their space, the ways they master, conquer and direct it, and the title could be "People and space". But I am afraid of pretentious titles, and I understand that people interact with the space through objects (even 
if they are "paranormalists").' At the same time, Tsivin added, 'People and Objects' was exceptionally 'painterly' among his works: the slipware coloured by oxides created a fresco effect: restrained blue, pink, terracotta and white colours alluded to the artist's fascination with medieval Russian frescoes. The painterly approach to human figures goes against the idea of ceramics as a material akin to human flesh, as the mythological origin of human beings, mentioned in Kapelian's manifesto. Playing on this metaphor was not typical for OK: for them, human figures alluded to images from easel art rather than to human physicality, and those works that show 'bio-plasticity' are remarkably non-anthropocentric. In Soviet decorative art of the 1970s, ceramics appears to be less comparable to human skin than does glass. For example, the sculpture 'Galatea' by Adolf Ostroumov from the Leningrad Factory of Artistic Glass is explicitly biomorphic and erotic (and obviously alludes to Vera Mukhina's 1952 glass torso achieved after a long series of efforts); ${ }^{4}$ the torsos from Tsivin's 1980s 'Antique' series represent Greek sculpture rather than human figures, marble and bronze rather than flesh.

'People and Objects', therefore, echoes a key tendency of decorative art at the time, pinpointed by such critics as Izotova and Kirill Makarov: the use of space as an active element of the composition and experimentation with sculptural and painterly techniques. ${ }^{95}$ Tsivin's people, interacting with space via objects, constitute what Izotova calls 'artefactual theatre' (predmetnyi teatr) that turns inward instead of integrating with the modernist architectural space of late socialism.

Theatre props and puppets, sculptural groups, painterly canvases and landscape architecture were all art forms that OK leaned towards in rejecting utilitarian objects. These works were often inspired by contemporary easel art - for example, Tsivin admitted that he was strongly influenced by the graphics and sculpture of Giacomo Manzù and Ernst Barlach, whose exhibitions were held in Leningrad in 1966 and in the early 1970s. ${ }^{96}$ Pondering the success of the exhibition among the creative intelligentsia across the USSR, Izotova suggested that ceramics revealed the tragicomic aspect of Petersburg culture, represented by the Petersburg stories of Nikolai Gogol, as opposed to the 'grey, cold and bleak official art'. She argued that each object here 'frivolously' denied its traditional function:

a plate dreamed of becoming a lake of unseen azure and generating nymphs and mermaids, pots turned into streetwise cats, clay clothes proved to be a double portrait-landscape, a chamotte ball cracked like a watermelon and 'treated' viewers to a fantastic still-life, a vase transformed into an urban courtyard, whereas colourful amphorae performed a leaf fall. ${ }^{97}$

However, carnivalesque imagery was only one aspect of OK's visual language. Many of the works, produced over the ten years of the group's activity, address such serious topics as time, freedom, faith, death and memory. 


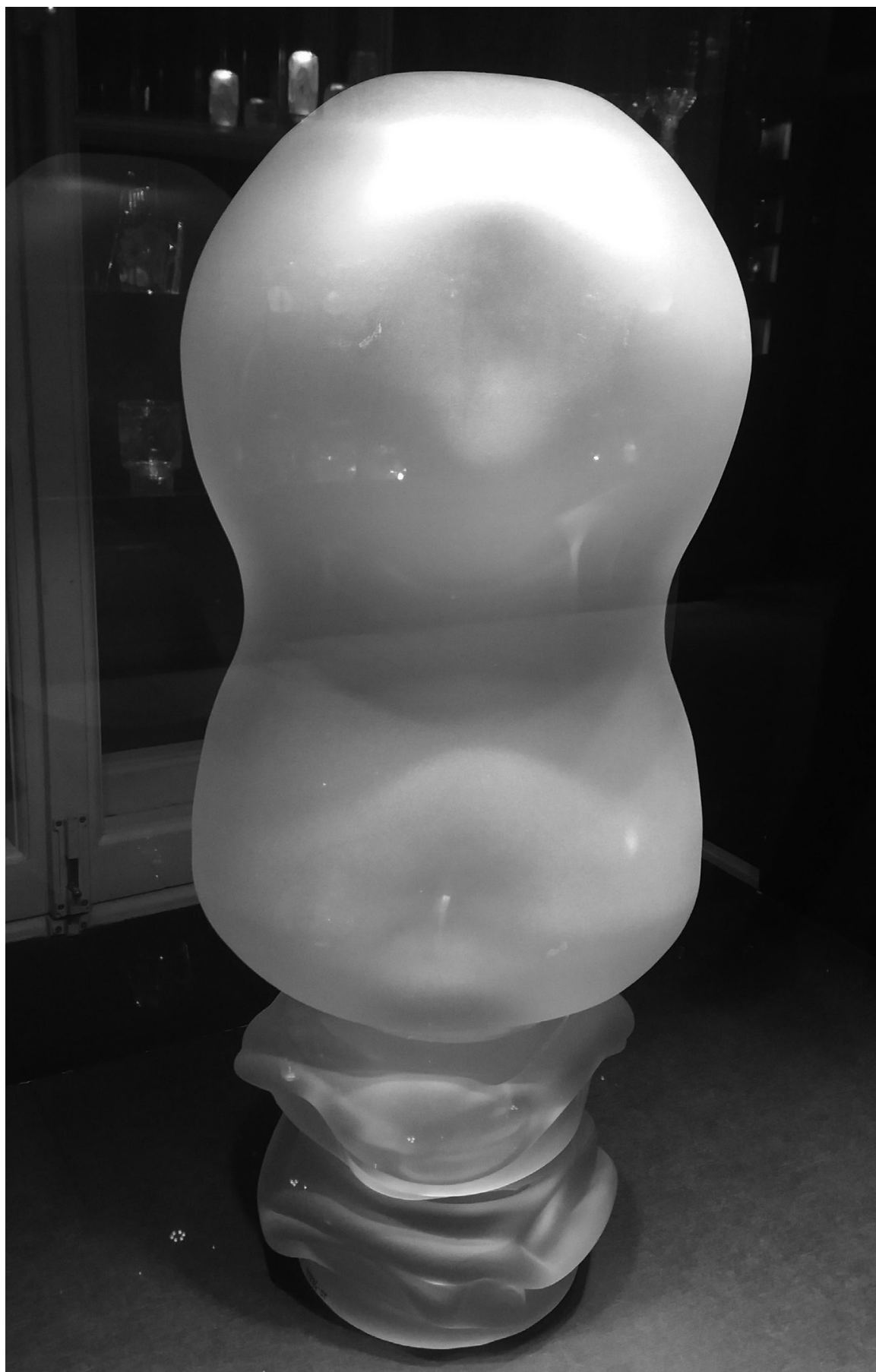

All rights reserved and permission to use the figure must be obtained from the copyright holder.

5.2 Adolf Ostroumov, sculpture, 'Galatea', lead glass, sandblasting, 1977. 
From the start, OK's work often showed signs of self-portrayal. The 1983 exhibition, on the suggestion of group participant Aleksander Zadorin, had a definite theme for the first time: self-portraiture. Many artists contributed installations representing themselves in studio environments (Aleksandr Gushchin, Zadorin), sculptural self-portraits as Renaissance artists (Mikhail Kopylkov, Elena Rudina), or otherwise expressed themselves through objects whose surface acted as a painterly canvas (Natalia Savinova, Natalia Rotanova, Vasilii Tsygankov). Some portrayed themselves as part of a collective, such as the family (Tsivin) or the actual OK group (Nina Kochneva). ${ }^{98}$ This exercise in self-reflection looks like the antithesis to Soviet production culture: the self-portraits say little about consumption and mass production. However, they do sometimes 'comment' on the position of a decorative artist in late Soviet society. For example, in her composition, produced at the Kombinat by the Leningrad potter Aleksandr Sokolov, NekrasovaKarateeva presents herself as an angel-like figure whose creative impulse is constrained by the 'wheel' of work and family responsibilities: the inscriptions on the wheel shafts are the names of institutions (LOSKh, the Art Fund, and the Mukhina School) and of the artist's two children and husband, as well as the word 'home'. Nekrasova-Karateeva's self-portrait, therefore, embodies the double burden of a female artist under state socialism (plate 16). ${ }^{99}$ Tired of the state's requirement to continuously design commodities, OK came close to institutional critique.

This critique did not focus on improving production cultures and achieving the productivist hope for setting comradely relations with useful objects. And OK's works were non-commodities not by virtue of their transparent relations with users (as the 1920s productivists would imagine); rather, these objects aspired for autonomy from Soviet economic and cultural institutions. They departed from the Khrushchev-era aesthetic regime of arts both through their diverse and provocative imagery and through their materiality. Instead of revealing the specificity of their materials, the OK artists, each in his or her own way, emphasised the properties of clay that produced sculptural or painterly effects. Today, the surviving participants attribute the group's nationwide acclaim to its universality and its status as a creator of 'image-ceramics', not of decorative art. Mikhail Kopylkov insists that 'decorative art' was just an official label, a requirement for the approval of the LOSKh authorities, while what he and his colleagues really created was a new kind of visual art. ${ }^{100}$ Likewise, Tsivin identifies his work during the OK period (and later, up to now) as sculpture rather than art ceramics. Referring to his teacher and role model Vasil'kovskii, he argues that a great artist 'can be great in all media'. ${ }^{101}$ While quite a few of OK's members worked in factories, the group offered a refuge from the still non-prestigious and undervalued status of the artist-in-industry. The development of the group's creative credo did not go without envy or competition, similarly to what happened 
with studio craft in the United States in the 1970s-1980s when it aspired for acceptance in the art world. As Glenn Adamson et al. conclude (referring to the arguments of Garth Clark), that effort of the American craftspeople was doomed 'partly because craft's medium-orientation was so at variance with the conceptual and cross-disciplinary tendencies of the art world'. ${ }^{102}$

In the Soviet context, however, medium-specificity also brought envy from easel artists. The official label 'decorative art' often acted as a pass for formal and conceptual experiments that would not be allowed in sculpture or painting. Deciding whether to accept an artwork for an official show, an exhibition committee needed to categorise it: due to its 'minor' status, ceramics accommodated greater artistic freedom. Tsivin's 'People and Objects' is an illustrative case. In 1985, while deciding whether it could go to a big all-Union exhibition 'We Are Building Communism', the Leningrad evaluation committee, composed of various honoured artists, had an argument over whether it was 'ceramics' or 'sculpture'. While the painter Evsei Moiseenko suggested that it was 'a beautiful thing' and that labels therefore did not matter, the sculptor Mikhail Anikushin demanded clear categorisation. With the verdict 'ceramics', 'People and Objects' went to Moscow to be featured among the best Soviet artworks. Admitting that he still has no hard feelings about those numerous committees, Tsivin recently remarked ironically that nobody bothered to ask if his people with objects were building communism. ${ }^{103}$ The artist implies that their looks and gestures were not directed to any communist utopia but elsewhere. In 2007 he created several variants of a clay sculpture representing a biblical theme: Jacob with the ladder. ${ }^{104}$

By 1986, when the changing political situation exacerbated differences in professional and ethical views within OK, envy grew from a motivational drive into a destructive, divisive force and the group disintegrated. Today it is remembered as a crucial, though perhaps underappreciated, group in late Soviet cultural and intellectual life. Its brainchild, izokeramika, was a way of interacting with contemporary trends in foreign studio ceramics (especially Japanese and British), to overcome ideological constraints and to suggest a model of autonomous material environment, or, rather, a set of diverse micro-environments. ${ }^{105}$ It was, at the same time, a child of Soviet institutions with their very specific material conditions and a product of Soviet technicians and craftsmen. The objects of izokeramika ultimately 'talked', therefore, about the impossibility of full artistic autonomy.

\section{Conclusion}

The Brezhnev government's dedication to furthering consumer culture in order to maintain the population's loyalty imposed a great responsibility not only on industrial designers, but also on decorative artists who were 
working in traditional art industries. Concurrently, increasing access to international cultural exchange and networking stimulated Soviet artists' creative ambitions and inspired them to pursue and intensify the late 1960s trend of challenging the established criteria of what constituted decorative art. As a result, the ideal of a proper, socialist, 'comradely' object ultimately disintegrated, while mutual mistrust between artists, on the one hand, and engineers, technicians and factory administrators, on the other, deepened. Dekorativnoe Iskusstvo SSSR's attempt, as a guide of the professional community, to promote a new, attractive and prestigious image of 'production culture' met with only limited success. While continuing to be dedicated to industry, decorative artists also gravitated towards experimentation with materials, forms and symbols that would set them apart from their earlier stomping grounds as mediators of mass production and consumption. Highly receptive to international developments both in studio craft and visual art, decorative artists used institutional support - in the form of workshops with kilns and the supply of clay, exhibitions, creative symposia, research trips and international competitions - as much as they could to grow as artists.

Aspiring for acceptance in the world of 'high art' and in the international community of studio crafts, Soviet decorative artists persistently tried to deconstruct the idea of a utilitarian object, resorting to non-traditional and unexpected uses of media. This aspiration was most evident in ceramics, and at the end of the Brezhnev and beginning of the post-Brezhnev period, Leningrad became the centre of a new artistic trend, image-ceramics. Applying Akrich's concept of script to this case, I argue that the artists of One Composition inscribed the burning questions of the late Soviet intelligentsia in their ceramics: the limits of personal freedom, the meaning of spirituality and religion in the modern world, collective and individual memory, the relationship between humans and nature. These scripts proceeded from the ideal of an autonomous artist, free from political, social and economic constraints. However, the implementation of these scripts was only possible because of state institutions and financing, and the physical work of craftspeople and technicians, which the artists could closely control in the Art Fund's workshops. It turns out that this script was a story of continuous interdependence between the artist and society rather than the tale of an autonomous artist.

\section{Notes}

1 RGALI, f. 2943, op. 1, d. 2550, 1. 53.

2 O. Baiar, 'Krasivoe v prostom', Dekorativnoe Iskusstvo SSSR 7 (1961), 1-6.

3 Leonid Nevler, 'Tut vse gorazdo slozhnee', Dekorativnoe Iskusstvo SSSR 3 (1963), 29-32.

4 'Vsesoiuznaia vystavka dekorativnogo iskusstva', Dekorativnoe Iskusstvo SSSR 9 (1970), 1. 
5 Attfield, Wild Things, p. 67.

6 'Govoriat spetsialisty', Dekorativnoe Iskusstvo SSSR 1 (1969), 34.

7 'Vsesoiuznaia vystavka dekorativnogo iskusstva'.

8 Vladimir Tsivin, interview with the author, recorded in St Petersburg, 26 March 2018. I encountered similar scepticism towards the art critiques of the past in conversations with the dynasty of decorative artists in St Petersburg in the summer of 2009

9 'Vsesoiuznaia vystavka dekorativnogo iskusstva', 3.

10 Ibid.

11 Ibid., 4

12 Ibid., 5.

13 Ibid., 6.

14 Brown, 'Thing Theory', 16.

15 'Obsuzhdaem vystavku. Govoriat kritiki', Dekorativnoe Iskusstvo SSSR 9 (1970), 9.

16 Ibid.

17 Ibid.

18 Ibid., 9.

19 Ibid., 11.

20 The Dekorativnoe Iskusstvo SSSR editorial from January 1962 presented decorative art as a sphere encompassing not only applied and monumental art, but also all sorts of decorative works (oformlenie) as well as folk crafts organised in the USSR through artisanal cooperatives (see introduction, p. 33). [AQ] 'XX s'”ezd KPSS I zadachi dekorativnogo iskusstva', Dekorativnoe Iskusstvo SSSR 1 (1962), 1-2.

21 'Obsuzhdaem vystavku. Govoriat kritiki', 11.

22 RGALI, f. 2943, op. 3, ed. khr. 581.

23 D. Bisti, 'Obshchnost' printsipov', Dekorativnoe Iskusstvo SSSR 1 (1973), 12-15.

24 N. Vasilevskaia, 'Tvorchestvo I proizvodstvo', Dekorativnoe Iskusstvo SSSR 2 (1973), 16.

25 Ibid.

26 This paragraph is based on Chernyshova, Soviet Consumer Culture in the Brezhnev Era, pp. 18-37.

27 'Khudozhnik i proizvodstvo', Dekorativnoe Iskusstvo SSSR 9 (1970), 20-1.

28 Ibid.

29 'Leningradskomu zavodu khudozhstvennogo stekla - 25 let', Dekorativnoe Iskusstvo SSSR 1 (1973), 15.

30 N. Voronov, 'Direktor', Dekorativnoe Iskusstvo SSSR 1 (1973), 17-19.

31 TsGANTD SPb, f. 1234, op. 11, d. 119, 1. 6.

32 Voronov, 'Direktor', 17.

33 N. Vasilevskaia, 'Glavnyi khudizhnik', Dekorativnoe Iskusstvo SSSR 1 (1973), 19-21.

34 TsGANTD SPb, f. 1234, op. 11, d. 119, 1. 7.

35 Ibid.

36 Natalia Chernyshova highlights the increase in the importation of consumer goods in the Brezhnev era: between 1970 and 1980 it doubled. Chernyshova, Soviet Consumer Culture in the Brezhnev Era, p. 31.

37 TsGANTD SPb, f. 1234, op. 11, d. 119.

38 'Khudozhestvennoe steklo zavodov SSSR', Dekorativnoe Iskusstvo SSSR 2 (1973), 12.

39 'Khudozhniki o svoem tvorhestve' (anketa Dekorativnoe Iskusstvo SSSR)', Dekorativnoe Iskusstvo SSSR 2 (1973), 13-14.

40 Ibid., 13.

41 The concept of the 'New Soviet Man/Person' has been addressed in several works over the last two decades. Some examples include Lilya Kaganovsky, 'How the Soviet Man Was (Un)Made', Slavic Review 63.3 (2004), 577-96, doi:10.2307/1520345; Tijana Vujoševic, Modernism and the Making of the Soviet New Man (Oxford: Oxford University Press, 2017). 
42 'Khudozhnik dolzhen videt' budushchee', Dekorativnoe Iskusstvo SSSR 10 (1973), 10-13.

43 Ibid.

44 Julia B. Chadaga, 'Embracing Stars: On the Corporeal Qualities of Russian Glass', Russian Studies Faculty Publications Paper 2 (2012), 17, http://digitalcommons. macalester.edu/russianfacpub/2 (accessed 2 August 2019).

45 Smirnov, Khudozhnik o prirode veshchei.

46 Alla Pavlinskaia, 'Talant i lichnost' khudozhnika', Dekorativnoe Iskusstvo SSSR 3 (1973), 35.

47 Leonid Pereverzev, 'Chelovek-veshch-chelovek', Dekorativnoe Iskusstvo SSSR 10 (1973), 1-7.

48 Editorial statement, Dekorativnoe Iskusstvo SSSR 10 (1973), 7-8.

49 Tretiakov, 'Biografiia veshchi'.

50 Madeleine Akrich, 'The De-Scription of Technical Objects', in W. Bijker and J. Law (eds), Shaping Technology/Building Society (Cambridge, MA: MIT Press, 1992), pp. 205-24.

51 Fallan, Design History, p. 79.

52 Editorial statement, Dekorativnoe Iskusstvo SSSR 10 (1973), 7.

53 Ibid., 8.

54 'Khudozhnik dolzhen videt' budushchee'.

55 Chernyshova, Soviet Consumer Culture in the Brezhnev Era, pp. 25-6.

56 'Seichas nam ne do khudozhnika', Dekorativnoe Iskusstvo SSSR 10 (1973), 14-17.

57 'Khudozhnik obiazab byt' konsruktorom', Dekorativnoe Iskusstvo SSSR 10 (1973), 22-5.

58 Nikita Voronov, 'Khudozhnik i inzhener: problem sotrudnichstva', Dekorativnoe Iskusstvo SSSR 10 (1973), 31-4.

59 Ibid.

60 Nikita Voronov, 'Ot chistoi formy - k izobrazitel'nosti', Dekorativnoe Iskusstvo SSSR 4 (1973), 20-5.

61 Ibid., 21.

62 The First International Symposium of Ceramics in Vilnius (Vilnius: The Unions of Artists of the USSR and of Lithuanian SSR, 1973); Juozas Adomonis, 'Vstrechi keramistov v Vil'niuse', in Stepanian and Aronov (eds), Sovetskoe dekorativnoe iskusstvo' 76, pp. 85-92.

63 Adomonis, 'Vstrechi keramistov v Vil'niuse'.

64 Ibid., 89.

65 Daston (ed.), Things That Talk, p. 15.

66 M. Ostroumova, 'Liricheskie obrazy', DISSSR 8 (August 1974), 17-22.

67 Chernyshova, Soviet Consumer Culture in the Brezhnev Era, pp. 164-5.

68 K. Ronskii, 'Khudozhnik i proizvodstvo', in Stepanian and Aronov (eds), Sovetskoe dekorativnoe iskusstvo' 76, pp. 94-7.

69 The Vilnius symposia were attended by an Italian delegation headed by art critic Edmondo Marabini from Faenza, an old ceramics centre. From 1971, thanks to Soviet links to the French and Italian Communist parties, Soviet artists were increasingly presenting their works at international ceramics competitions in Faenza, where Marabini was the secretary, and at the International Ceramics Biennale in Vallauris, southern France, where Picasso experimented with studio ceramics in the 1940s-50s. The First International Symposium of Ceramics in Vilnius, p. 5; RGALI, f. 2082, op. 3, d. 859, 1. 2.

70 Margarita Izotova, 'Predmet i ego sreda', in Stepanian and Aronov (eds), Sovetskoe dekorativnoe iskusstvo' 76, pp. 49-60.

71 Ibid., p. 50.

72 Margarita Izotova and Mikhail Kopylkov, Odna kompositsiia (St Petersburg: Novaia Niva, 2011), p. 11. 
73 Mikhail Kopylkov, telephone conversation with the author, 7 November 2018.

74 Izotova and Kopylkov, Odna kompositsiia, p. 31.

75 Adomonis, 'Vstrechi keramistov v Vil'niuse'.

76 Vladimir Tsivin, conversation with the author, recorded in St Petersburg, 26 March 2018.

77 Izotova and Kopylkov, Odna kompozitsiia, p. 39.

78 Vladimir Tsivin, Kommentarii (St Petersburg: Avrora Dizain, 2008), p. 64.

79 Gusarova, 'Leningradskaia keramika', pp. 62-3.

80 The Institute of Painting, Sculpture and Architecture in Leningrad was the successor to the Imperial Academy of Arts. After a number of reorganisations in the 1920s, it acquired the name of the nineteenth-century realist painter Ilya Repin in 1932. A number of its graduates from the late 1930s would teach at the Mukhina School from the 1950s, in particular in the department of artistic ceramics and glass.

81 Tsivin, Kommentarii, p. 64.

82 Ibid., p. 19.

83 Izotova and Kopylkov, Odna kompozitsiia, pp. 15-29.

84 Olga Nekrasova-Karateeva, conversation with the author, recorded in St Petersburg, 1 December 2017.

85 Izotova and Kopylkov, Odna kompozitsiia, p. 16.

86 Tsivin, conversation, 26 March 2018.

87 Quoted in Izotova and Kopylkov, Odna kompositsiia, p. 12.

88 Tsivin, Kommentarii, p. 183.

89 Olga Nekrasova-Karateeva, interview with the author, recorded in St Petersburg, 17 March 2014.

90 'Naturstil' 70-kh', Dekorativnoe Iskusstvo SSSR 12 (1979), 6.

91 Kirill Makarov, 'Naturstil' 70-kh', Dekorativnoe Iskusstvo SSSR 2 (1979), 24.

92 Brown, Things, p. 15.

93 Tsivin, Kommentarii, p. 53.

94 Chadaga, 'Embracing Stars', 18-19.

95 Izotova, 'Predmet I ego sreda', 51; Makarov, 'Naturstil' 70-kh', 22.

96 Tsivin, Kommentarii, pp. 22-8.

97 Izotova and Kopylkov, Odna kompositsiia, p. 11.

98 All these works can be seen in Izotova and Kopylkov, Odna kompositsiia, pp. 172-88, available at http://glassceram.ru/wp-content/uploads/2013/04/odna_komposicija. pdf (accessed 2 August 2019).

99 Olga Nekrasova-Karateeva, email correspondence with the author, 14-20 November 2018.

100 Kopylkov telephone conversation, 7 November 2018.

101 Tsivin conversation, 26 March 2018.

102 Adamson et al., 'Modern Craft Studies: The Decade in Review', 7, citing Garth Clark, 'How Envy Killed the Crafts Movement', in Glenn Adamson (ed.), The Craft Reader (Oxford: Berg, 2010), p. 448.

103 Tsivin Kommentarii, p. 54.

104 Vladimir Tsivin, Skul'ptura (St Petersburg: Avrora dizain, 2008), pp. 170-4.

105 Mikhail Kopylkov, 'Afterword', in Izotova and Kopylkov, Odna kompozitsiia, pp. 314-15; Nekrasova-Karateeva interview, 1 December 2017. 